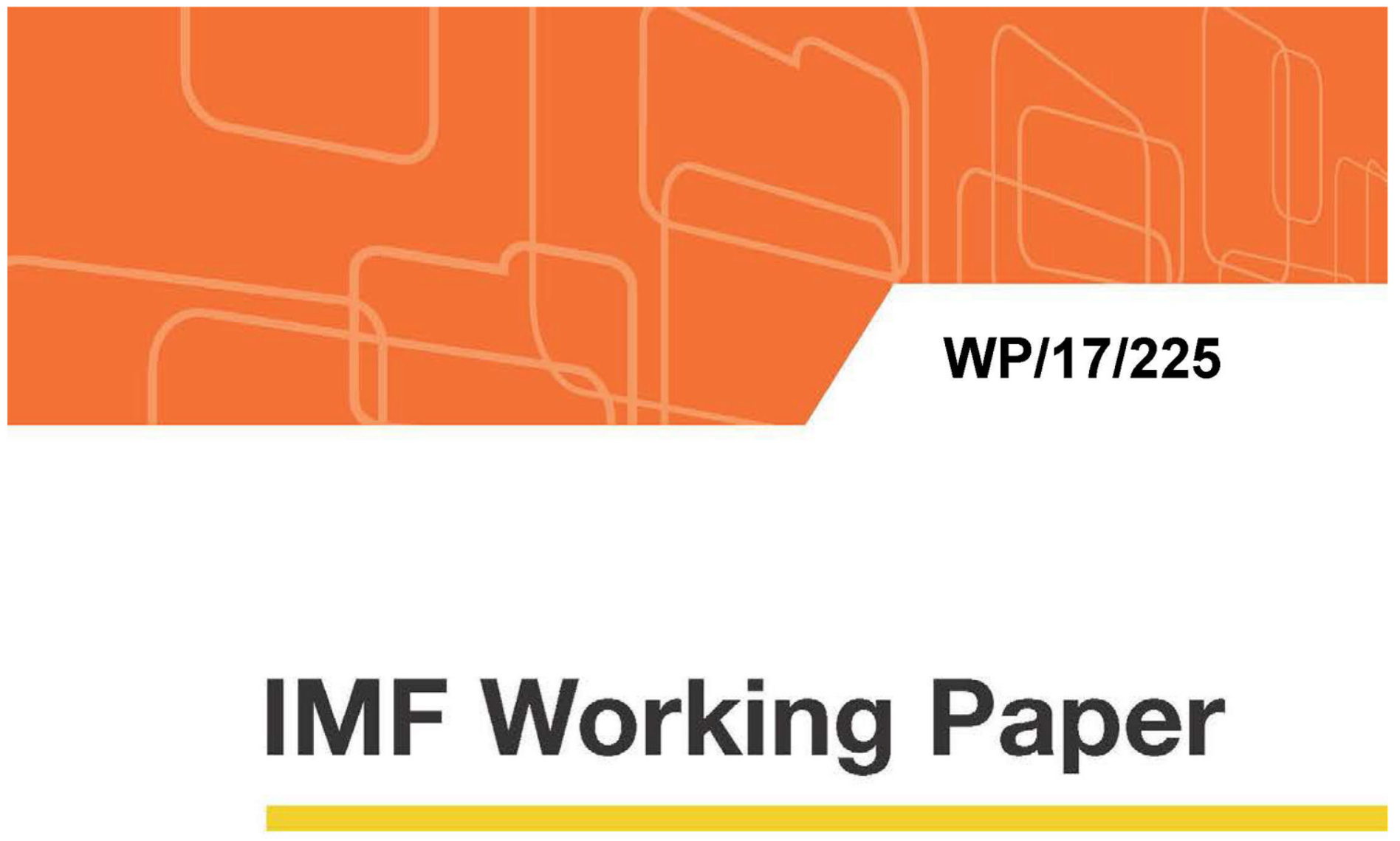

\title{
Inequality in Brazil: A Regional Perspective
}

by Carlos Góes and Izabela Karpowicz

IMF Working Papers describe research in progress by the author(s) and are published to elicit comments and to encourage debate. The views expressed in IMF Working Papers are those of the author(s) and do not necessarily represent the views of the IMF, its Executive Board, or IMF management. 


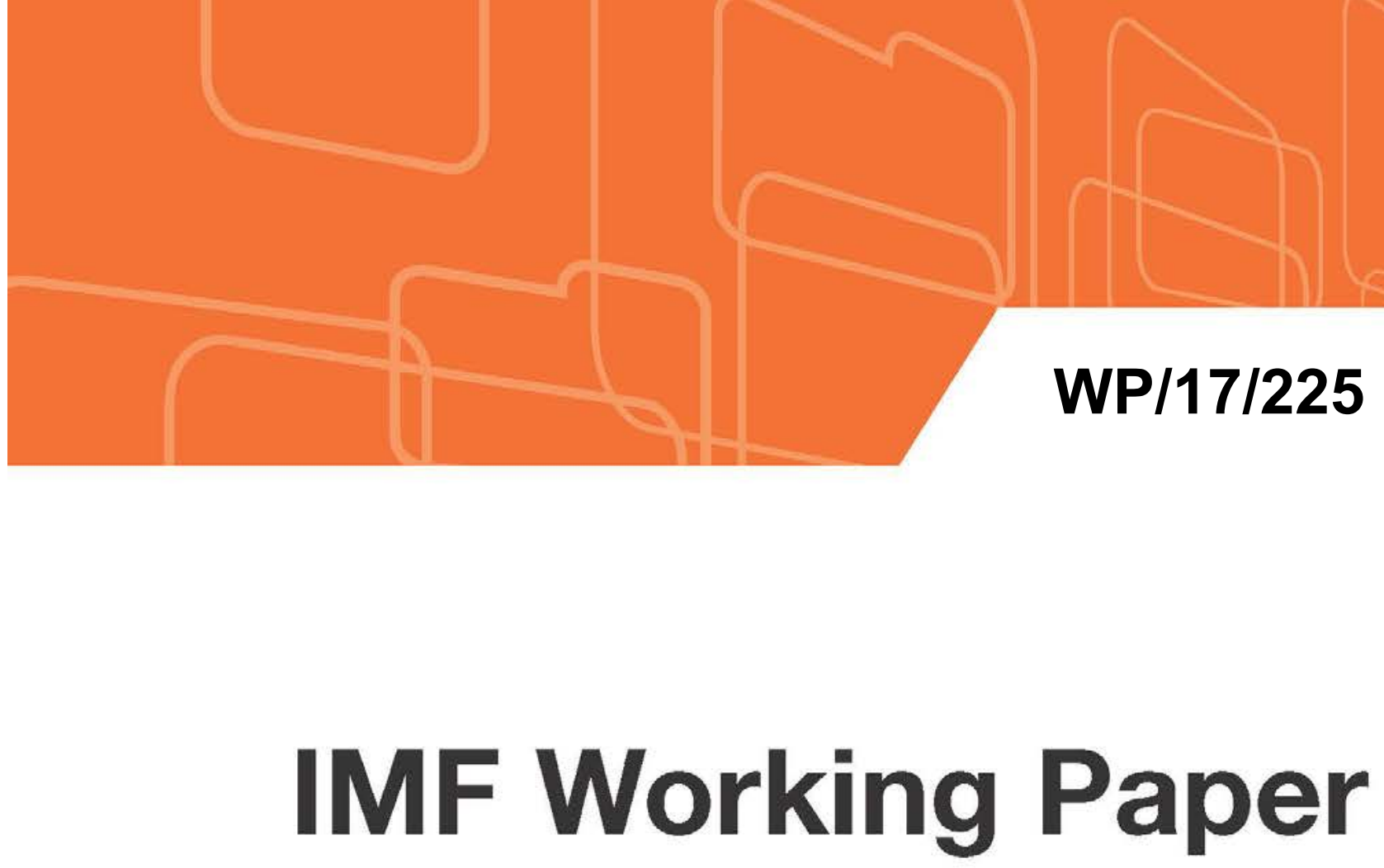

\section{Inequality in Brazil: A Regional Perspective}

by Carlos Góes and Izabela Karpowicz

IMF Working Papers describe research in progress by the author(s) and are published to elicit comments and to encourage debate. The views expressed in IMF Working Papers are those of the author(s) and do not necessarily represent the views of the IMF, its Executive Board, or IMF management.

$$
\text { I N T E R N A T I O N A L M O N E T A R Y F U N D }
$$




\title{
IMF Working Paper
}

Western Hemisphere Department

\section{Inequality in Brazil: A Regional Perspective}

\section{Prepared by Carlos Góes and Izabela Karpowicz ${ }^{1}$}

\author{
Authorized for distribution by Alfredo Cuevas
}

September 2017

\section{IMF Working Papers describe research in progress by the author(s) and are published to elicit comments and to encourage debate. The views expressed in IMF Working Papers are those of the author(s) and do not necessarily represent the views of the IMF, its Executive Board, or IMF management.}

\begin{abstract}
In this study, we document the decline in income inequality and a convergence in consumption patterns in Brazilian states in a new database constructed from micro data from the national households' survey. We adjust the state-Gini coefficients for spatial price differences using information on households' rental prices available in the survey. In a panel regression framework, we find that labor income growth, formalization, and schooling contributed to the decline in inequality during 2004-14, but redistributive policies, such as Bolsa Familia, have also played a positive role. Going forward, it will be important to phase out untargeted subsidies, such as public spending on tertiary education, and contain growth of public sector wages, to improve budgetary efficiency and protect gains in equality.
\end{abstract}

JEL Classification Numbers: C33, D31, D63, H52, H53, O15.

Keywords: income inequality, redistribution policies, Brazil.

Author's E-Mail Address: carlos.goes@presidencia.gov.br; ikarpowicz@imf.org

\footnotetext{
${ }^{1}$ We thank Branko Milanović, Emmanuel Skoufias, Alfredo Cuevas, Roberto Perrelli, Marina Mendes, Metodij Hadži-Vaskov, Davide Furceri, Raphael Espinoza, Jorge Alvarez, Xavier Debrun, Pedro Souza, Sergei Suarez Dillon Soares, Henrique Barbosa, and the participants of the seminar at the Ministry of Finance in Brasilia for their helpful comments. All errors and omissions are solely ours.
} 


\section{TABLE OF CONTENTS}

$\begin{array}{ll}\text { ABSTRACT } & \underline{2} \\ \text { A. Overview } & \frac{3}{4} \\ \text { B. Historical Trends in Regional Inequality 2004-14 } & 4 \\ \text { C. Macro-Policies and Inequality Outcomes: Stylized Facts and Regression Analysis __ } \frac{10}{19} \\ \text { D. Conclusions }\end{array}$

\section{BOXES}

1. The Cost of Living Adjustment

2. Returns to Education and Public-Private Wage Gap $\underline{13}$

3. An Example of Poorly Targeted Transfers: Public Universities $\underline{15}$

\section{FIGURES}

1. Convergence in the Consumption of Goods by Households $\underline{5}$

2. Income Inequality in Brazilian States: A Dynamic Decade $-\frac{7}{8}$

3. Income Inequality in Brazilian States: Some Evidence of Convergence ___ $\underline{8}$

4. Income Inequality in Brazilian States - Disaggregated ___ $\underline{9}$

5. Income Inequality in Brazilian States - Convergence in the Middle ___ $\underline{10}$

\section{APPENDICES}

I. Data and Sources $\underline{20}$

II. Econometric Results and Tables $\underline{22}$ 


\section{A. Overview}

Over the past decade or so, Brazil—a still highly unequal country — has been the poster child for social mobility. According to the World Bank's international poverty line, Brazil slashed poverty from 25 percent of the population in 2004 to 8.5 percent in 2014. Extreme poverty declined from 12 to 4 percent over the same period. ${ }^{2}$ As millions were lifted out of poverty, the middle class was boosted. The most commonly used inequality measure - the Gini coefficient (the closer to 1, the more unequal) - declined from 0.60 in 1990 to 0.51 in 2014 according to World Bank's data. Inequality reduction was achieved thanks to a decade-long period of economic growth and deliberate income and social inclusion policies, such as minimum wage increases and targeted social programs. Yet, inequality remains high: based on data from the 2014 Pesquisa National de Amostra de Domicílios (PNAD), labor income of the population in the top decile of the income distribution corresponds to 40 percent of labor income of all Brazilian families, the top 1 per cent receives about 12 percent, and the top 0.1 per cent around 2.5 percent. Half percent of all labor income is concentrated in the top 0.01 percent.

The recession that started in 2014 is likely to have affected the pace of progress on the social dimension. Earnings from work continue to be the main source of income for the poorest, who are suffering disproportionately from job losses. Rising unemployment and compressed households' disposable incomes are affecting their living standards and jeopardizing social mobility. Indeed, unemployment reached 13 percent in 2017, but has been higher for lowerskilled labor. ${ }^{3}$ But even after the recession, the government will face a long period of fiscal consolidation. To observe the cap on federal government non-interest expenditures, restraint will be necessary across all categories of spending in the medium term.

In this paper, we construct a new database in which we aggregate individual and households survey data from the annual PNAD and correct households' incomes for spatial price differences across different regions in the country. We use this data to study the evolution and the drivers of income inequality in Brazil. To our knowledge, we are the first to apply the methodological techniques from the literature on global income inequality spearheaded by Milanović and his co- authors, and recently updated in Lakner and Milanović (2015), to gain insights on both within- and between-state inequality in Brazil. Another novelty of our paper is the use of a

\footnotetext{
${ }^{2}$ Households whose income is less than $\$ 3.10$ a day/less than $\$ 1.90$ for extreme poverty at constant 2011 PPP-adjusted U.S. dollars.

${ }^{3}$ By early-2017, more than one in four young adults in Brazil were unemployed.
} 
spatial price differences index that we construct from PNAD data to allow comparability of nominal incomes across states with unequal living standards. Because of the nature of the data employed, we focus mainly on inequality of outcomes, and do not study inequality of opportunities, such as access to education and health services, clear water and sanitation, and quality infrastructure.

We find that the decline in overall inequality in Brazil was driven by both falling inequality within states and income convergence across states. We look at the evolution of income and consumption patterns for specific income percentiles of the national income distribution over time and show that income convergence was more evident around the median of the state distributions. From our regressions we find that most of the change in Gini can be explained by income growth, higher schooling levels and labor formalization, but the targeted social program, Bolsa Família, also contributed to income convergence. Civil servants' wage growth has, in contrast, slowed gains in equality. The reforms necessary to ensure fiscal sustainability should incorporate the objective of improving spending efficiency while avoiding adverse effects on income distribution. As labor formalization and income growth are slowing down, going forward, better targeting of social benefits, rationalizing the tax system, and moderating civil servants' wages will be key for preserving gains in equality.

The paper is organized as follows: in Section B, we describe the evolution of inequality in Brazilian states and regions over the past decade using a novel data set; in Section C, we present a regression analysis to study the policy drivers of the decrease in inequality; and we conclude in Section D.

\section{B. Historical Trends in Regional Inequality 2004-14}

In this section, we analyze the historical trends in inequality in Brazil based on the new database constructed using micro-data from the Brazilian households' survey (PNAD) and adjusted for spatial price differences. Because of the nature of the data we are using, we focus mainly on inequality of outcomes, and do not study inequality of opportunities, such as access to health, clear water and sanitation, and quality infrastructure. We base our estimates of inequality on after-tax per capita income as reported in the PNAD, which includes data on labor income, retirement benefits, social security benefits, and income from financial and real assets.

Growth in incomes over the past decade has allowed the poorer segments of the population to increase their consumption of durable goods. With access to electricity being nearly universal across all income levels already in 2004, access to durable goods increased substantially for all 
households over the following 10 years (Figure 1). But how have overall incomes behaved and what is the state of income inequality today?

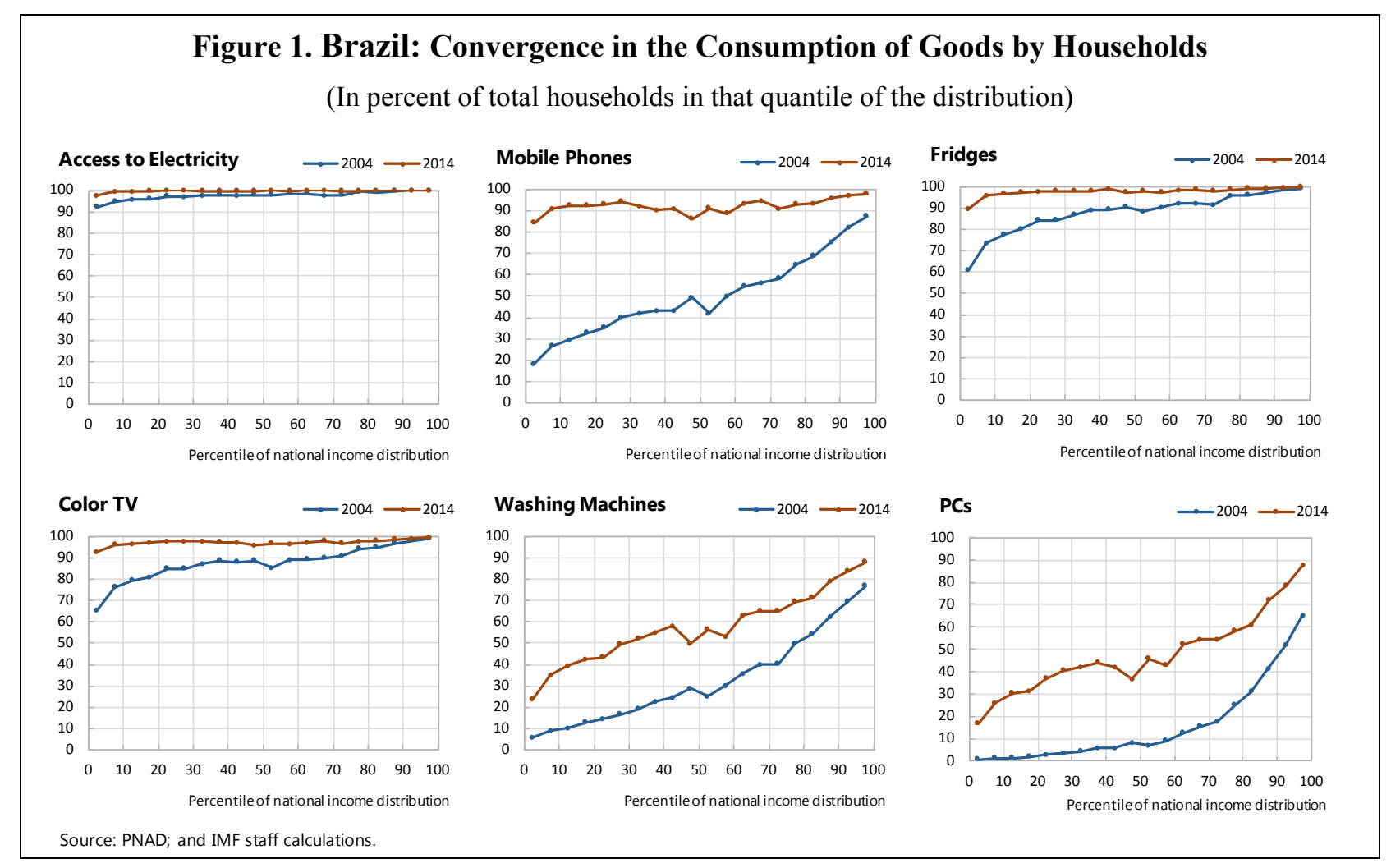

Income inequality in Brazil has declined. The Gini coefficient for Brazil published by the Brazilian Institute of Statistics (IBGE) fell from 0.54 in 2004 to 0.49 in 2014, and other commonly used inequality measures also show declining trends. We construct a Gini coefficient based on the income reported by individuals and households in the annual survey (PNAD) administered by the IBGE, adjusting household incomes for spatial prices differences throughout the country (Box 1). Our "adjusted" Gini index has declined at the level of the country form 0.55 to 0.50 over the same period. The usefulness of this adjusted income measure is in facilitating comparisons

\section{Brazil: Gini Index}

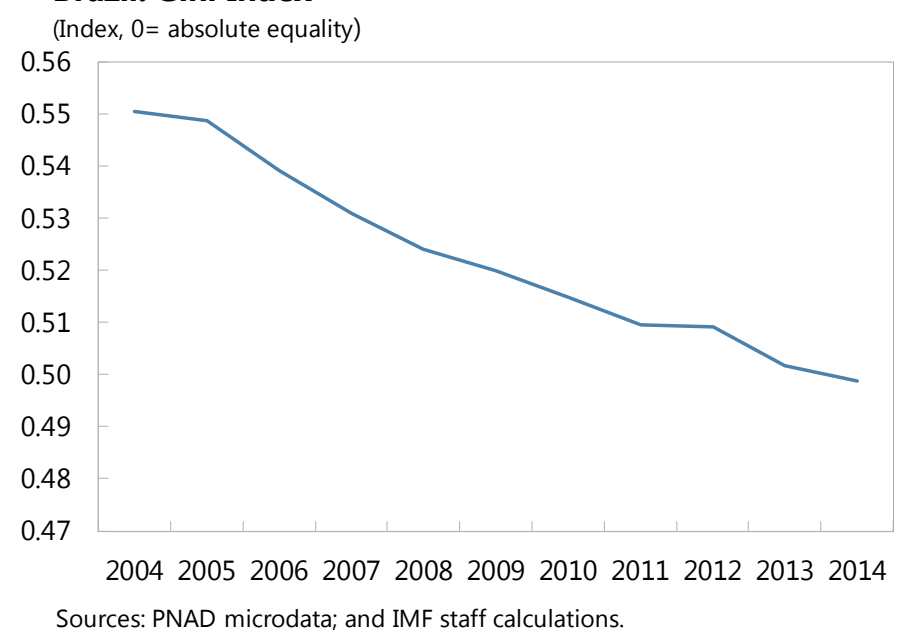
across states. 


\section{Box 1. The Cost of Living Adjustment}

Inequality measures must take into account differences in the cost of living across and also within countries to distinguish between nominal and real differences in incomes. Cross-country inequality studies, such as Lakner and Milanović (2015) or Dollar and others (2013) for instance, typically correct the between-country income statistics using PPP conversions, often based on national price indices. But adjusting for living standards is important also when studying inequality within large countries because, as highlighted by Deaton and Dupriez (2011), the Balassa-Samuelson effect may cause richer regions to show permanently higher price levels. Indeed, price levels are not homogeneous in Brazil. Góes and Matheson (2017) have documented large divergences of productspecific price dynamics, particularly for non-tradables, across different metropolitan areas. Almeida and Azzoni (2016) showed that overall price level differences in Brazilian metro areas can diverge with levels as low as -19 percent and as high as +14 percent from the national average.

Because micro-data for consumer-price level differences is not available in Brazil we use information on rental prices as a proxy. The consumer price indices are available only for the 12 metropolitan areas, insufficient to capture the potentially ample differences in living costs across Brazilian states. Using data on declared households' rent prices from the PNAD and other characteristics of the dwelling (such as the number of rooms or area in square meters) we adjust households' incomes for spatial price differences in a two-step procedure. The advantage of using rental price data for the adjustment is that most of the price dispersion generally comes from non-traded goods, and especially housing. Li and Gibson (2014), for instance, have used data on dwelling sales in urban China to develop spatially-disaggregated indices of house prices which they used as spatial deflators for both provinces and core urban districts.

First, for each sub-region $k=[1,2, \ldots, 7]^{\prime}$ of each state $s=[1,2, \ldots, 27]^{\prime}$ and each year $t=$ $[2004, \ldots, 2015]$ ', we construct a rental spatial price difference index, which measures the percent deviation of the per room average rental price from the national average:

$$
r_{s, k, t}=\frac{m_{s, k, t} / n_{s, k, t}}{m_{t}^{*} / n_{t}^{*}}-1
$$

where $m$ is the average monthly rent price for the cluster $s, k$, while $n$ is the average number of rooms per household for the cluster, and the stars denotes national averages.

Given that overall spatial price differences can be well approximated by a linear function of housing spatial price differences, we use the parameter from Azzoni and Almeida (2016), assumed to be homogenous across regions, and our heterogeneous rental spatial-price difference index to fit an overall spatial price difference index $\hat{p}_{s, k, t}=\phi r_{s, k, t}$ Finally, we use $\hat{p}_{s, k, t}$ to obtain adjusted households incomes, which are then used in the analysis of income distributions and their trends.
Brazilian Metro-Areas: Correlation Between Overall and Housing Spatial Price Differences (In deviations from national averages)

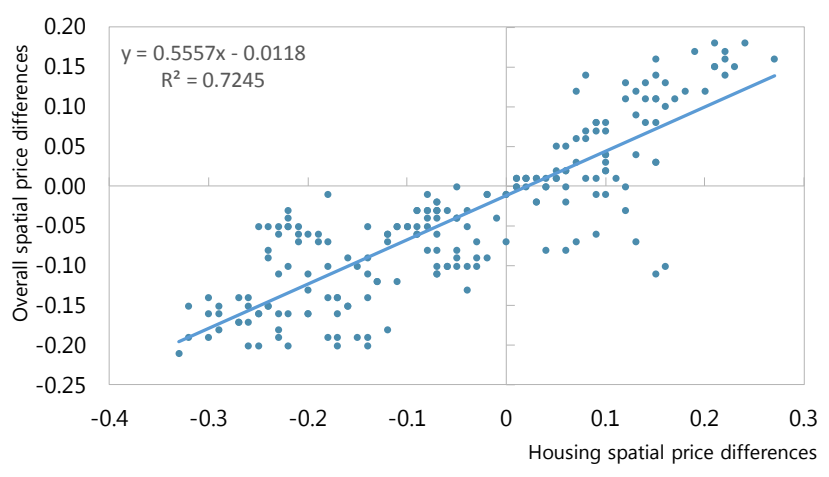

Sources: Almeida and Azzoni (2016); PNAD microdata; and IMF staff calculations. 


\section{Box 1. The Cost of Living Adjust (Concluded)}

Our estimates of the overall Gini coefficients are nearly perfectly correlated with the official estimates of the IBGE. Higher households income per capita regions tend to face price levels above the national average, while lower income regions tend to face price levels below the national average. Thus, adjusting for spatial price differences compresses nominal differences in incomes and decreases the overall inequality indicator. The estimated coefficient shown in the figure (less than one) denotes the compression effect of the adjustment.

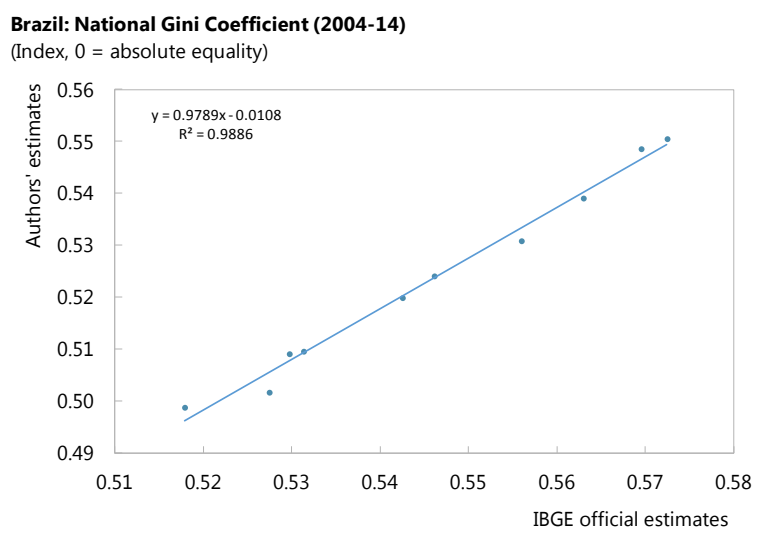

The decline in inequality was pronounced in the period studied, including among regions. Within-state income distributions vary from state to state. In 2014, the Gini coefficient of the most unequal state was 18 percent higher than the national Gini ratio, whereas the Gini of the least unequal state was almost 20 percent lower than the national ratio. These differences are, however, narrower than in the past: the standard deviation of state Gini coefficients decline from 0.035 to 0.033 between 2004 and 2014. Between-states inequality has decreased as a share of total inequality as incomes grew faster in the poorer regions of the North, Northeast, and Midwest (blue, navy, and yellow lines below). Convergence in average incomes led to a decreasing share of total inequality explained by between-state inequality, as depicted also by the Generalized Entropy and Atkinson's indices. ${ }^{4}$

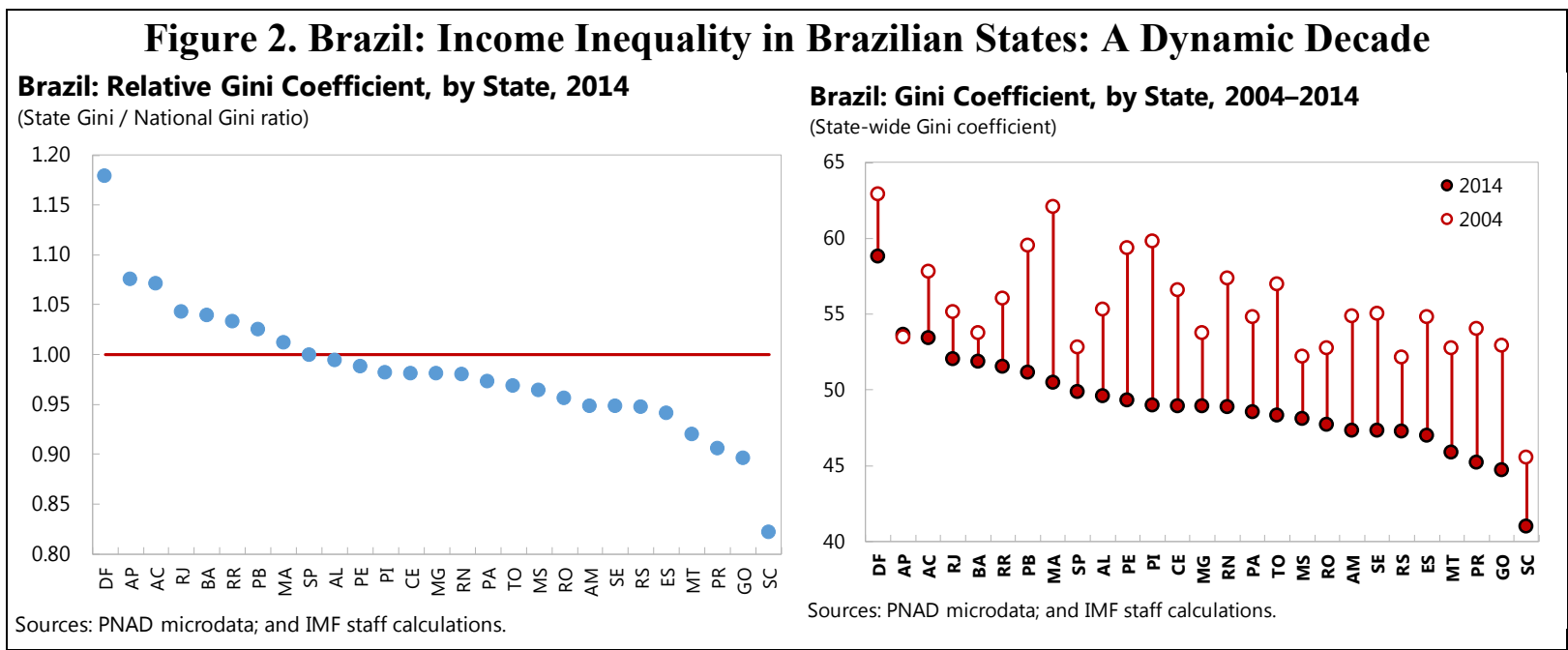

\footnotetext{
${ }^{4}$ The Generalized Entropy (GE) and Atkinson (A) indices, used as consistency checks, are perfectly decomposable into within and between components.
} 


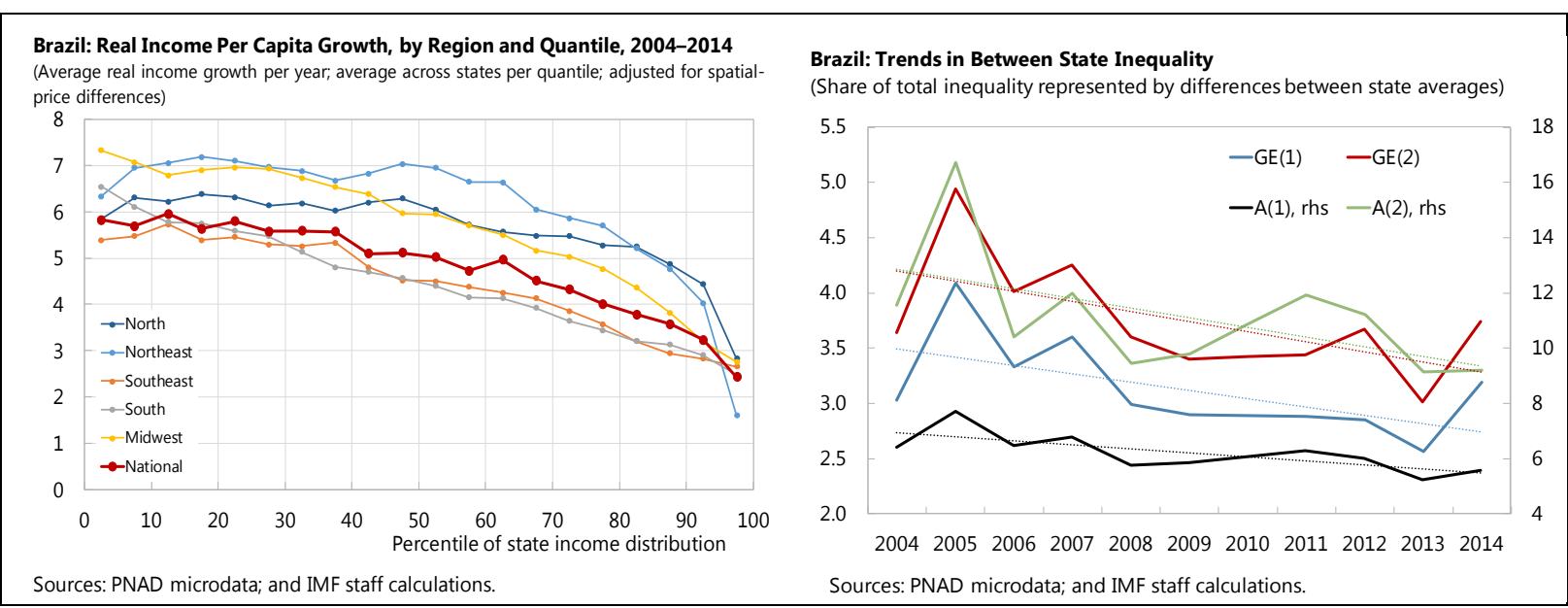

Inequality within states also dropped. This was driven primarily by substantially higher income growth rates for lower-income households in nearly all states. Inequality has declined relatively more in the states with higher initial inequality in 2004, especially after excluding the outliers (SC and DF), which illustrates convergence in within-state inequality indices across the country.

\section{Figure 3. Brazil: Income Inequality in Brazilian States: Some Evidence of Convergence}
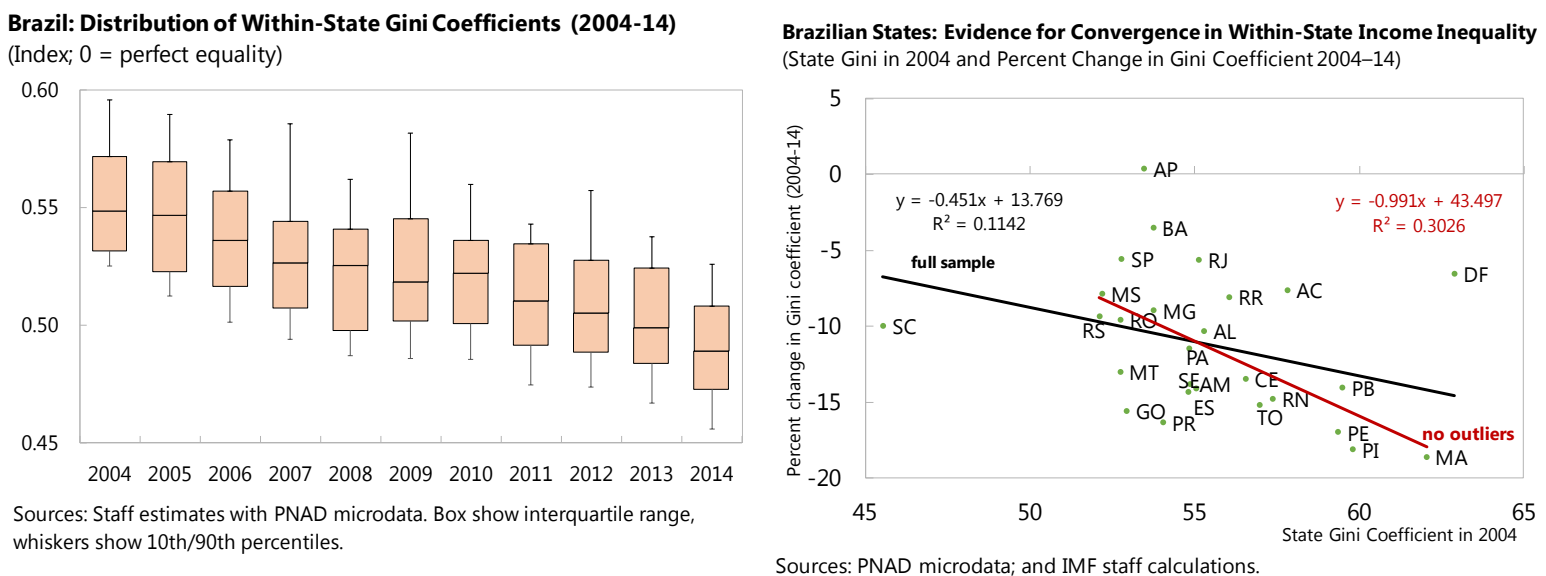

In Figure 4, we explore how within-state income distributions fit into the national income distribution. ${ }^{5}$ Households belonging to the lowest and those belonging to the highest deciles of the state income distribution also belong to the lowest/highest deciles of the national distribution. In other words, the living standards of the lowest-earning and those of the highestearning are similar across states and regions. However, depending on the state, the state median household income can fall anywhere between the $30^{\text {th }}$ and the $70^{\text {th }}$ percentile of the national distribution. These differences have shrunk over time, as shown by a more pronounced

\footnotetext{
${ }^{5}$ The different colors in Figure 4 represent households' income per capita distributions of states that belong to the region. For a legend of states see Appendix I.
} 
downward shift of the curve depicting the standard deviation of percentiles between the states and the national income distribution around the $30^{\text {th }}$ to $70^{\text {th }}$ percentiles since 2004 (Figure 5).

\section{Figure 4. Brazil: Income Inequality in Brazilian States - Disaggregated}

\section{Brazil: Household Income per Capita Distribution, by State, 2004}

(Percentiles of state-wide and nation-wide household income distribution, PPP adjusted)

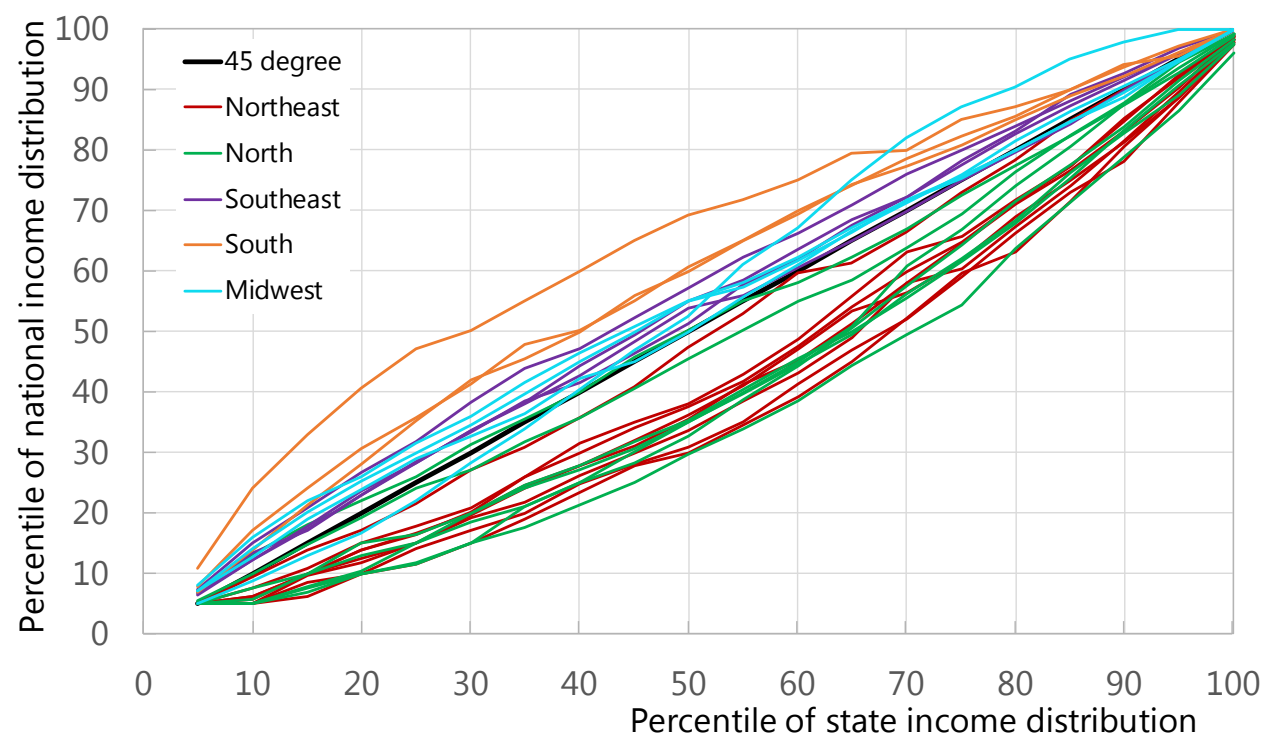

Sources: PNAD microdata; and IMF staff calculations

\section{Brazil: Household Income per Capita Distribution, by State, 2014}

(Percentiles of state-wide and nation-wide household income distribution, PPP adjusted)

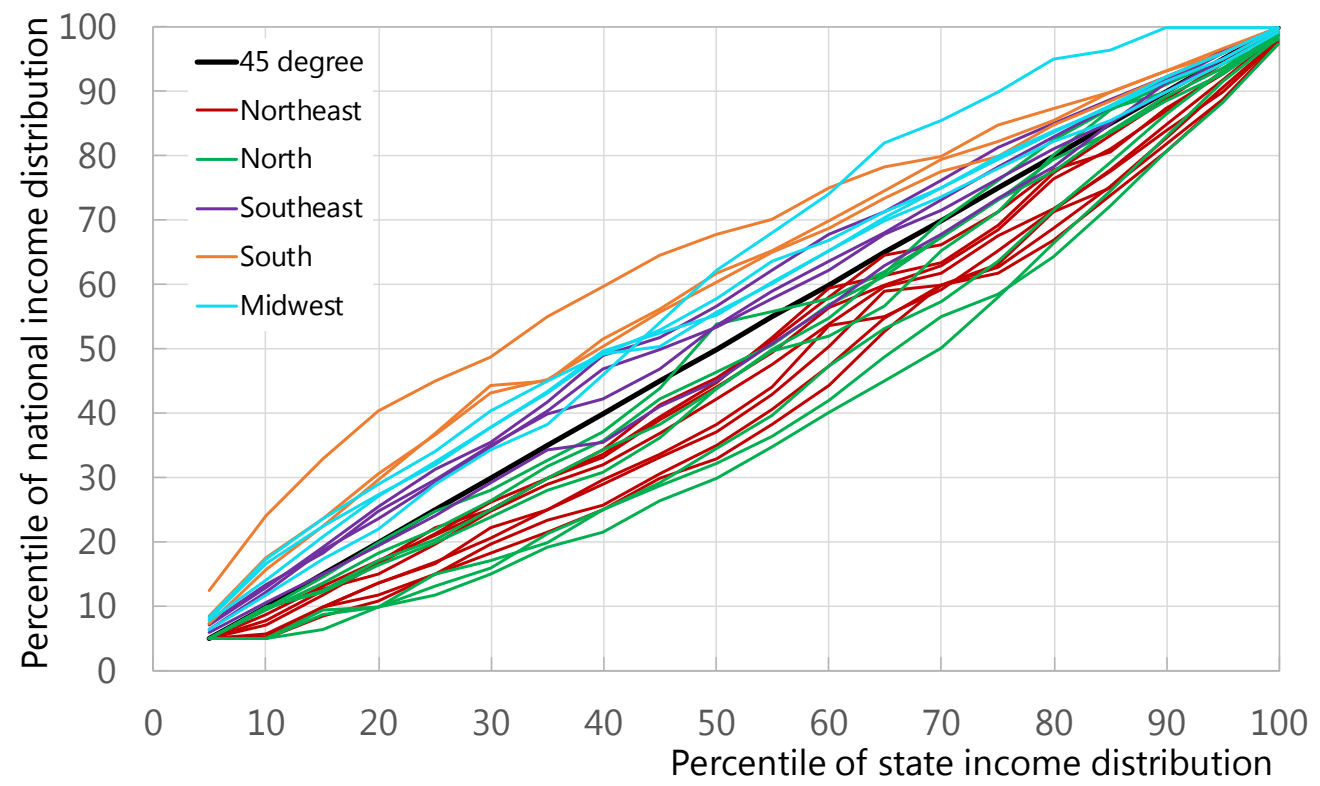

Sources: PNAD microdata; and IMF staff calculations. 


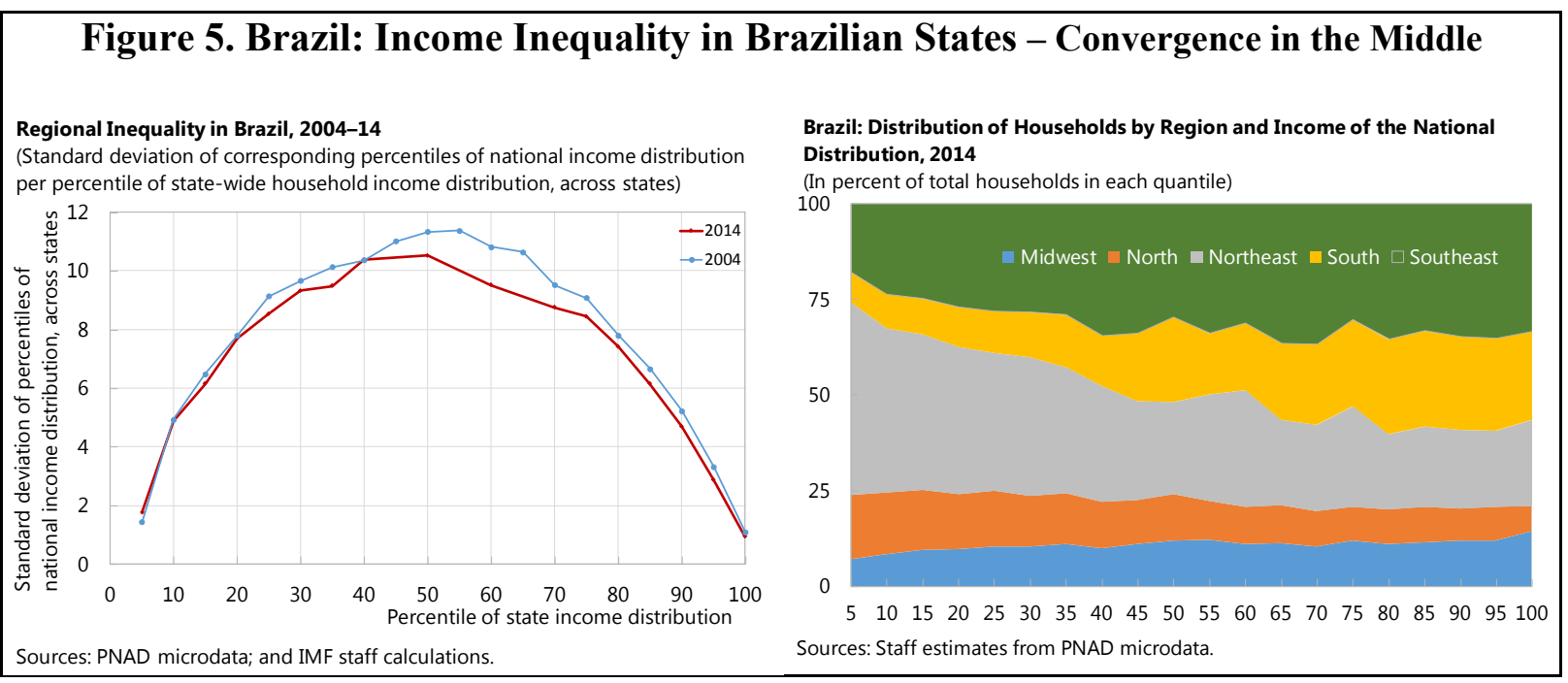

There is no evidence of reversal of progress with equality in the most recent PNAD (2015). With the drop in employed population, real gross households' earnings contracted in 2015 across all professions and for the first time in 11 years. The real income decline touched the entire income distribution, but, as it was more severe in the higher income brackets, inequality fell slightly. The official Gini index calculated for all income sources fell from 0.497 in 2014 to 0.491 in 2015. The Gini calculated for labor income fell from 0.490 to 0.485 and, in the case of household income, from 0.494 to 0.493 .

However, the continuation of the recession through 2016 may have dented equality gains.

Earnings from work represent a higher share of total income in the survey and a higher share of the income of households in the lowest quartile. As job destruction continued through 2016, and inflation remained high, the relatively poorer households have suffered more. Preliminary 2016 inequality estimates from $F G V$ Social suggest that inequality widened slightly for the first time in 22 years. The World Bank (2017) has estimated that the number of poor in Brazil will likely increase by 2.5-3.6 million by 2017, while the Gini index will increase from 0.51 to $0.52-0.54$. Among the "new poor", young, skilled workers in the service sector will represent the higher share of those falling below the poverty line due to the crisis.

\section{Macro-Policies and Inequality Outcomes: Stylized Facts and Regression Analysis}

\section{i. Stylized Facts}

\section{Tax policy}

If achieved through progressive taxation, increases in tax revenues can be correlated with declining inequality. Brazil's overall tax system relies relatively more on indirect taxes, which 
are regressive. ${ }^{6}$ Effective personal income tax (PIT) rates, which take into account all the admissible deductions (green line in the chart), do not seem progressive either. However, taking into account the taxation of dividends at corporate level the system's progressivity appears to be restored (red line). Applying standard benefit-tax incidence analysis, Lustig and others (2014) find that personal income taxes in Brazil are progressive and redistributive,

Brazil: Effective PIT Rates 1/ (Income tax rate, by cohort)

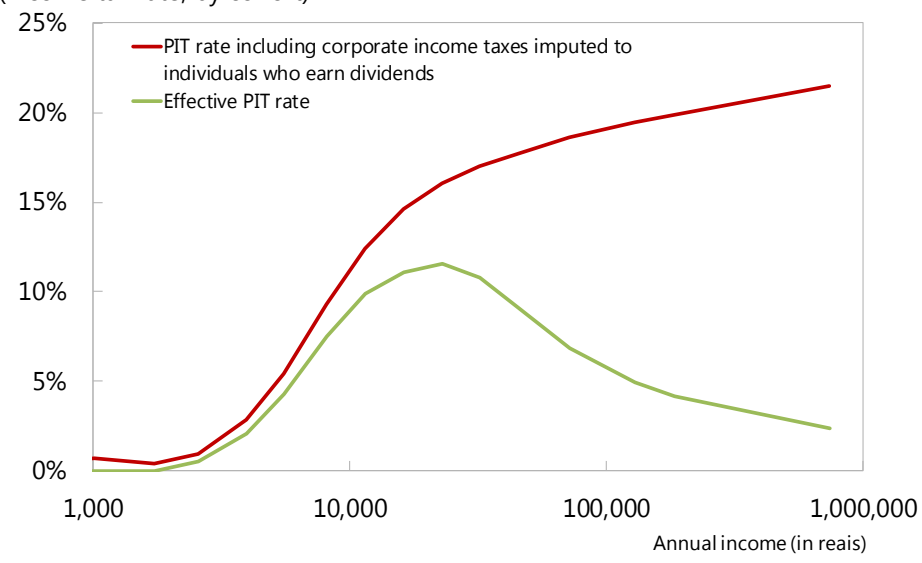

Sources: Staff estimates with Receita Federal (Grandes Números, IRPF) data. 1/ Since dividends deductions are intended to avoid double taxation, we augment each cohort's tax burden by adding $15 \%$ of the corporate income tax (IRPJ) and $9 \%$ of the CSLL.

and contributed to reducing the Gini of after-tax incomes by 1.9 percent in 2009.

\section{Minimum wage and expenditure policies}

Supported by strong growth, the minimum wage policy in Brazil has sustained upward social mobility for lower classes. The effect of the minimum wage policy on inequality is ambiguous, given its potentially offsetting impact on employment and inflation (Jaumotte and Osorio Buitron, 2015). According to Maurizio (2014), increases in the minimum wage in Brazil led to wage compression, which helped to reduce inequality among wage earners. Indeed, the average hourly wage for a worker with a given level of education rose much faster among the poor than for the rest of the population in the last decade mainly because of the minimum wage policy. This occurred, however, as the increase in the real minimum wage above productivity was accompanied by a decline in the unemployment rate supported by Brazil's relatively strong output growth, helped in turn by favorable factors, such as high commodity prices (IMF, 2015). In such an environment, the trade-off between redistribution and employment embedded in the minimum wage policy was less apparent. But Brazil's contraction in investment and growth

\footnotetext{
${ }^{6}$ The ratio of direct to indirect taxes at the general government level was 45 percent in 2016. Brazil relies more on indirect taxes than other Latin American economies and significantly more than OECD countries (OECD, 2010). According to Amaral and others (2016), the average Brazilian worker pays 15 percent of his gross income in income taxes, 3 percent in asset taxes, and 24 percent in consumption taxes. Those making up to $\mathrm{R} \$ 3,000$ per month pay 24 percent of their gross income in consumption taxes, while those making more than 10,000 pay 17 percent in consumption taxes. While personal income taxes are progressive, excessive reliance on consumption taxes makes the overall system regressive.
}

(continued...) 
after 2014 has reduced labor demand, putting pressures on employment and wages. Further minimum wage increases above productivity growth may affect employment negatively, with the effect being more pronounced for the unskilled workers (IMF, 2015; Jaumotte and Osorio Buitron, 2015). This would in turn lead to higher before-tax (or gross) inequality. ${ }^{7}$

Public sector wage increases were systematically above private sector wage growth and have contributed to a wider difference in average wage levels over time. According to the hedonic theory of wages (Rosen 1974 and 1986), public sector wages should be lower than private sector ones because public sector employees have more stable formal jobs and, at least in Brazil, enjoy higher retirement

Brazil: Real Annual Earnings, per Sector (12-month rolling change)

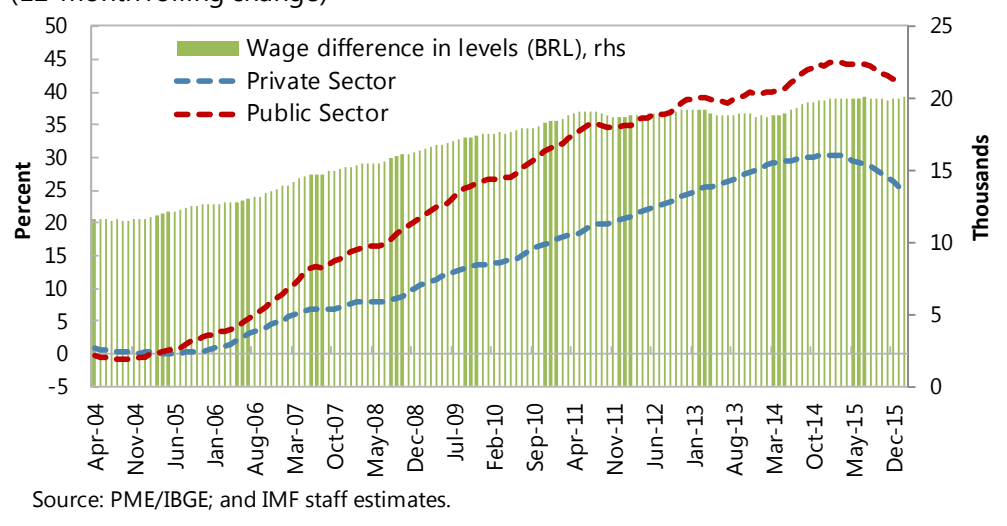
benefits (Cuevas and others 2016 and IMF, 2017). Nevertheless, many studies in the literature find evidence of public sector wage markups in the literature (Clements and others, 2010) including in Brazil (Souza and Medeiros, 2012; Braga and others, 2009). In 2014, the estimated median premium on public sector jobs across comparable professions was about 50 percent up to the secondary education level (Box 2). To the extent that public sector workers' incomes are higher than private sector workers', stronger growth of wages in the public sector may have moderated equality gains achieved in the recent decade.

Bolsa Familia is Brazil's flagship social assistance program for reducing poverty. Beneficiary coverage has increased from about 6.5 million households in 2004, when it was founded, to over 14 million in 2014 (56 million people). Budgetary appropriations for the program have also increased from about 0.3 percent of GDP to 0.6 percent of GDP over the same period. The World Bank (2017) estimates that 58 percent of the decline in extreme poverty in Brazil over

\footnotetext{
${ }^{7}$ According to Silva and others (2015), in over 1/3 of manufacturing firms, value added per worker in 2012-13 increased slower than minimum wage, putting at risk further employment and wage gains, particularly among firms with high concentration of workforce in wage levels around the minimum wage.
} 
2004-14 was due to Bolsa Família

transfers. Soares and others (2006) report that in 2005 about 80 percent of the Bolsa Familia and other cash-targeted programs (Bolsa Escola, PETI, etc.) went to families below the poverty line (half of the minimum wage per capita) and that the program was responsible for 21 percent of the decline in the Gini coefficient between 1995 and 2005.

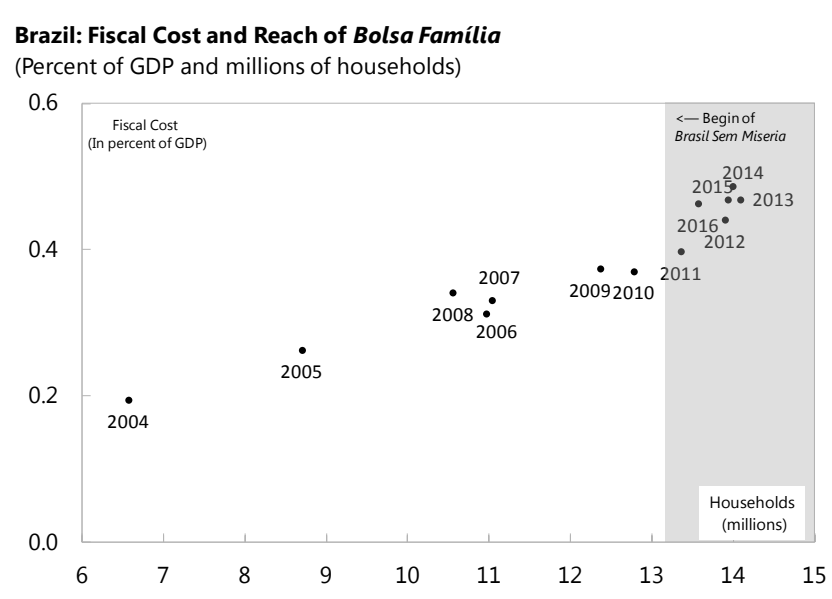

Sources: Ministry of Social Development; and IMF staff calculations.

\section{Box 2. Returns to Education and Public-Private Wage Gap}

We estimate the returns on education in Brazil by means of two "Mincer" regressions (Mincer, 1974) with identical specifications that relate the log of wages to years of schooling and experience for the public and the private sector separately, for each period $t=[2004, \ldots, 2014]^{\prime}$. The model contains more than 50 other controls:

$$
\begin{aligned}
& \ln \left(w_{i, t}\right)=\alpha_{t} s_{i, t}+\beta_{1, t} e_{i, t}+\beta_{2, t} e_{i, t}^{2}+\gamma_{t} m_{i, t}+\sum_{n=1}^{4} \delta_{n, t} r_{i, n, t}+\sum_{n=1}^{13} \zeta_{n, t} o_{i, n, t}+\sum_{n=1}^{13} \theta_{n, t} a_{i, n, t}+ \\
& \sum_{n=1}^{10} \phi_{n, t} c_{i, n, t}+\sum_{n=1}^{27} \psi_{n, t} d_{i, n, t}+\epsilon_{i, t}
\end{aligned}
$$

where $w_{i, t}$ is the monthly wage for person $i$ at period $t ; s_{i, t}$ is the years of formal schooling; $e_{i, t}$ is the years of experience (defined as the individual's age minus years of schooling minus 6 - the age when mandatory education starts); $m_{i, t}$ is a gender dummy; $r_{i, n, t}$ are dummies for races; $o_{i, n, t}$ are dummies for occupations (formal/informal worker, military, civil servant, domestic worker, self-employed, etc.); $a_{i, n, t}$ are dummies for sectoral economic activities (agriculture, industry, manufacturing, construction, commerce, etc.); $c_{i, n, t}$ are dummies for worker's class (director, middle management, administrative, sales, etc.); $d_{i, n, t}$ are dummies for the Brazilian states; and $\epsilon_{i, t}$ is the error term.

In the second step, we use the estimated coefficients from the regressions to generate two vectors of fitted values for each one of the $\sim 150$ thousand workers in the sample who belong to either the private or the public sector. The fitted values show the expected log wages for individuals, given the same set of observable characteristics.

We find that predicted earnings are an increasing function of the years of schooling in Brazil for public as well as private sector jobs, but earnings among those in public sector jobs are consistently higher, in line with Souza and Medeiros (201 and 2013b). Up to the secondary education level, the 25

Brazil: Predicted Returns on Schooling, 2014

(In log of monthly wages given years of formal education; distribution of predicted wages given $50+$ controls for geography, demographics, experience, education, industry, management level, etc.)

9

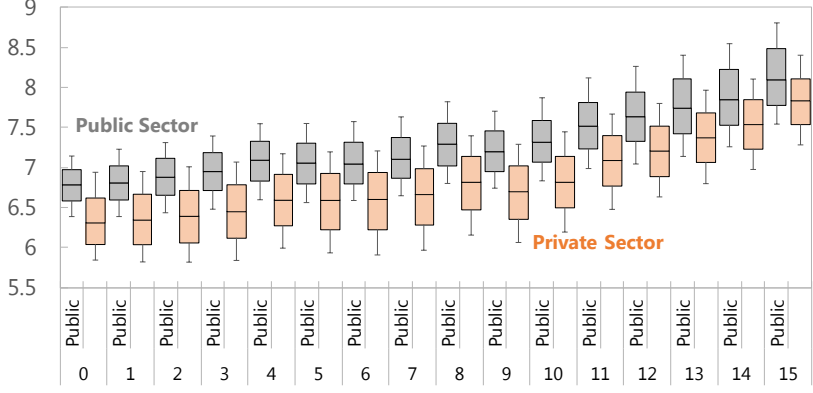

Sources: PNAD microdata; and IMF staff calculations. Boxes show interquartile range. Whiskers show 10th/90th percentiles. We ran Mincerian regressions with the same controls for a sample of $\sim 150,000$ obs, calculated predicted values from coefficients resulting from the private and public sectors, and ploted the distributions. percent lowest predicted earnings in the public sector are higher that the median earnings in the private sector. 


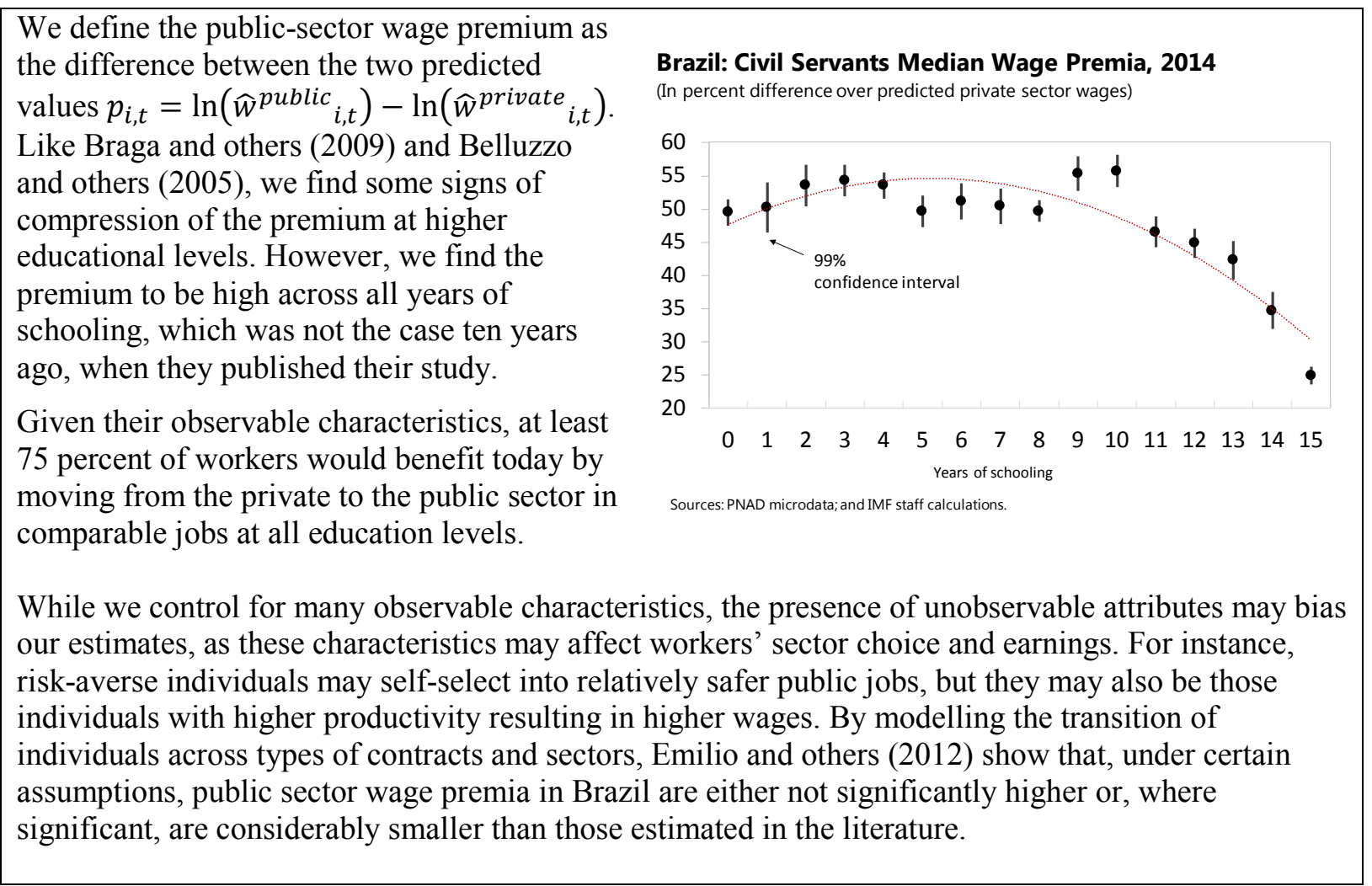

Even when they don't worsen income inequality by themselves, implicit education subsidies use up resources that could otherwise be employed to improve income equality. While spending on education may be concomitantly pro-growth and pro-equality (Ostry and others, 2014), it can be also seen as a blanket subsidy and weakly targeted transfers generally constitute an inefficient use of scarce resources. In Brazil, public universities are tuition-free. They are also more accessible to children of wealthier parents, who often have studied in private primary and secondary schools (World Bank, 2016). Indeed, nearly half of the public university student population in the PNAD survey belongs to households in the top quartile of the income distribution, while only 9 percent of university students come from families in the bottom quartile (see Box 3). This type of implicit subsidy benefits the rich disproportionally. Equality of opportunities could be enhanced by redistributing resources away from tertiary education towards improving provision of early childhood and primary schooling which would improve overall spending progressivity (IMF, 2014). 


\section{Box 3. An Example of Poorly Targeted Transfers: Public Universities}

Over the past decades, the educational level of Brazilians improved significantly. The share of population between 20 and 22 years old that completed at least secondary education increased from 45.5 percent in 2004 to 60.8 percent in 2014, according to data from the PNAD. The improvement was widespread across regions, as depicted by the curves shifting to the right in the figure. At the same time, Brazil has expanded access to tuition - free, tax payer-funded public universities. Between 2000 and 2014 the number of students in public universities more than doubled-from 0.89 million to 1.96 million (Ministry of Education, INEP, 2015).

Students from better-off households are overrepresented in public universities. Nearly half of the public university student population in the sample belongs to households in the top quartile of the income distribution, while only 9 percent of university students comes from the bottom quartile. Meanwhile, about 40 percent of the younger cohorts of the Brazilian population still fails to complete secondary education.

By updating Góes and Duque (2016), we provide a more robust evidence of the relationship between income and access to public universities. We estimate a logit model with PNAD data to obtain the probability of being public university

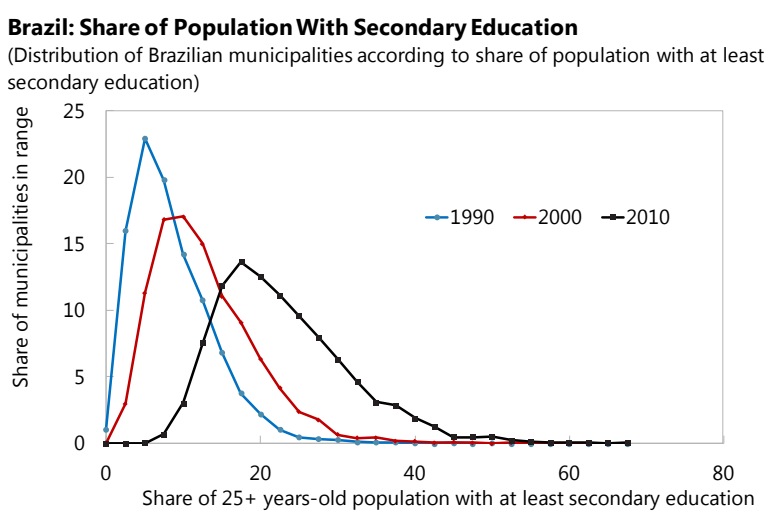

Sources: IMF staff calculations with census data compiled by UNDP.

Brazil: Overrepresentation of Top Quartile in Public Universities, 2014 (Share of overall population and public unversity population which belong to each quartile of household income per capita)

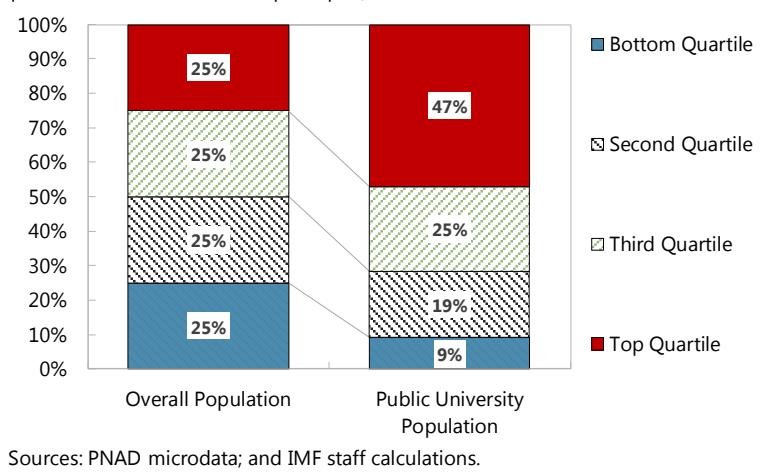
student for individuals between 17 and 24 years old conditional on household's income per capita and a set of controls:

$$
\operatorname{Pr}\left(y_{i}=1 \mid f_{i}, X_{i}\right)=\frac{e^{\phi f_{i}+X_{i}^{\prime} \gamma}}{1+e^{\phi f_{i}+X_{i}^{\prime} \gamma}}, \quad y_{i} \in\{0,1\}
$$

where $y_{i}$ is a categorical variable denoting a student currently in a public university for individual $i, f_{i}$ is household family income per capita and $X_{i}^{\prime}$ is a set of individual controls - which include age, gender, race and regional dummies (Appendix II, Table 6).

We find that, even after controlling for geographic and demographic characteristics, students from richer households are considerably more likely to attend public universities. In fact, a student in the $25^{\text {th }}$ percentile of the income distribution has a 2 percent probability of attending a public university while the one in the $99^{\text {th }}$ percentile has more than 30 percent probability of attending it. Although the relationship between income and university attendance is

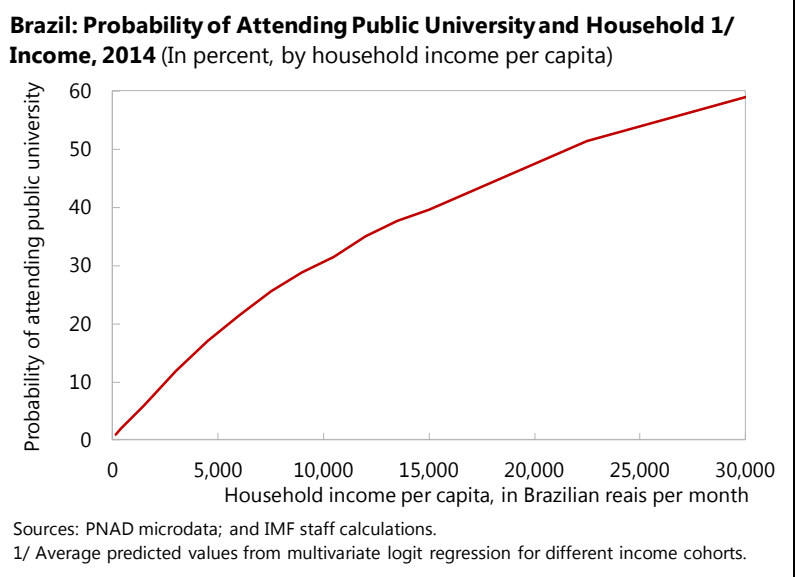




\section{Box 3. An Example of Poorly Targeted Transfers: Public Universities (Concluded)}

not necessarily causal, the finding is consistent with the intuitive diagnostic that children with richer parents, who can afford to study in private primary and secondary schools, obtain easier access to publicly-funded universities (World Bank, 2016).

Redirecting government spending from tertiary to primary and secondary education would improve overall welfare and equality. Funding a student at the higher education level costs about four times as much as funding a student at the secondary education level in Brazil. This ratio is much higher than the OECD average of 150 percent (OECD, 2014). Given that many Brazilians do not complete secondary education and the rate of return to investment in human capital tends to be higher at lower levels of education (Heckman, 2008), targeting education spending on the poor and cutting subsidies to the rich can generate fiscal savings while making the access to education fairer, and ultimately equality of opportunities better.

\section{ii. Regression Results}

Below we present the results from the analysis of the drivers of changes in inequality in a regression framework. We use our data set constructed from the PNAD by aggregating individual data into state-level inequality indicators. ${ }^{8}$ We complement the state-level data with information on annual Bolsa Família state budgets and federal income tax revenues collected in states.

We run two sets of regressions. First, we regress the income of the top and bottom quartiles on the average income, civil servants' income, tax revenues, the share of formal sector workers in total employment, the share of civil servants in total employment, schooling, and the per capita Bolsa Familia budget for each state, adding state dummies to control for time-invariant statespecific characteristics. Complete results are in Table 4 of Appendix II and the model is formally specified below.

$\left\{\begin{array}{l}y_{s, t}^{Q 1}=\alpha_{1} y_{s, t}+\beta_{1} b_{s, t}+\omega_{1} t_{s, t}+c_{s, t}^{\prime} \gamma_{1}+l_{s, t}^{\prime} \phi_{1}+h_{s, t}^{\prime} \xi_{1}+c_{1, s}+u_{1, s, t} \\ y_{s, t}^{Q 4}=\alpha_{2} y_{s, t}+\beta_{2} b_{s, t}+\omega_{2} t_{s, t}+c_{s, t}^{\prime} \gamma_{2}+l_{s, t}^{\prime} \phi_{2}+h_{s, t}^{\prime} \xi_{2}+c_{2, s}+u_{2, s, t}\end{array}\right.$

where $y_{s, t}^{Q 1}$ and $y_{s, t}^{Q 4}$ are the natural logs of spatially price-adjusted average household income per capita for the bottom and top household income per capita quartiles for state $s$ in year $t ; y_{s, t}$ is the natural log of spatially price-adjusted average household income per capita; $b_{s, t}$ is the natural log of spatially price-adjusted Bolsa Familia per capita expenditures; $t_{s, t}$ are revenues from personal and corporate income taxes collected at the federal level as a share of state GDP;

\footnotetext{
${ }^{8}$ See Appendix I for more details on the data sources and the construction of variables.
} 
$c^{\prime}{ }_{s, t}=\left[w_{s, t}, k_{s, t}\right]^{\prime}$ is a vector of civil servants' characteristics, with $w_{s, t}$ as the natural log of spatially price-adjusted average household income per capita of households headed by civil servants and $k_{s, t}$ as the share of civil servants in the state's workforce; $l_{s, t}^{\prime}=\left[e_{s, t}, f_{s, t}\right]^{\prime}$ is a vector of labor market characteristics, with $e_{s, t}$ as the employment rate and $f_{s, t}$ as the

formalization rate; $h_{s, t}^{\prime}=\left[h_{s, t}^{Q 1}, h_{s, t}^{Q 4}\right]^{\prime}$ is a vector of educational characteristics, with $h_{s, t}^{Q 1}$ and $h_{s, t}^{Q 4}$ as the average schooling, in years, for the bottom and top household income per capita quartiles; $c_{1, s}$ and $c_{2, s}$ are the state-specific intercepts; $u_{1, s, t}$ and $u_{2, s, t}$ are residuals.

By looking separately at the top and bottom quartiles of the income distribution over the period (Figure 6), we find that bottom quartile incomes have been more responsive to overall income growth than top quartiles. In addition, increased schooling significantly raised incomes of the poor, but did not affect incomes of the top quartile. Bolsa Familia had a higher impact on the bottom quartile incomes, but also appears to have increased the income of the top quartile, likely due to the high estimated multiplier effect of the program. ${ }^{9}$ Finally, labor formalization and civil servants' incomes have had opposite effects on the growth of top and bottom quartile income.

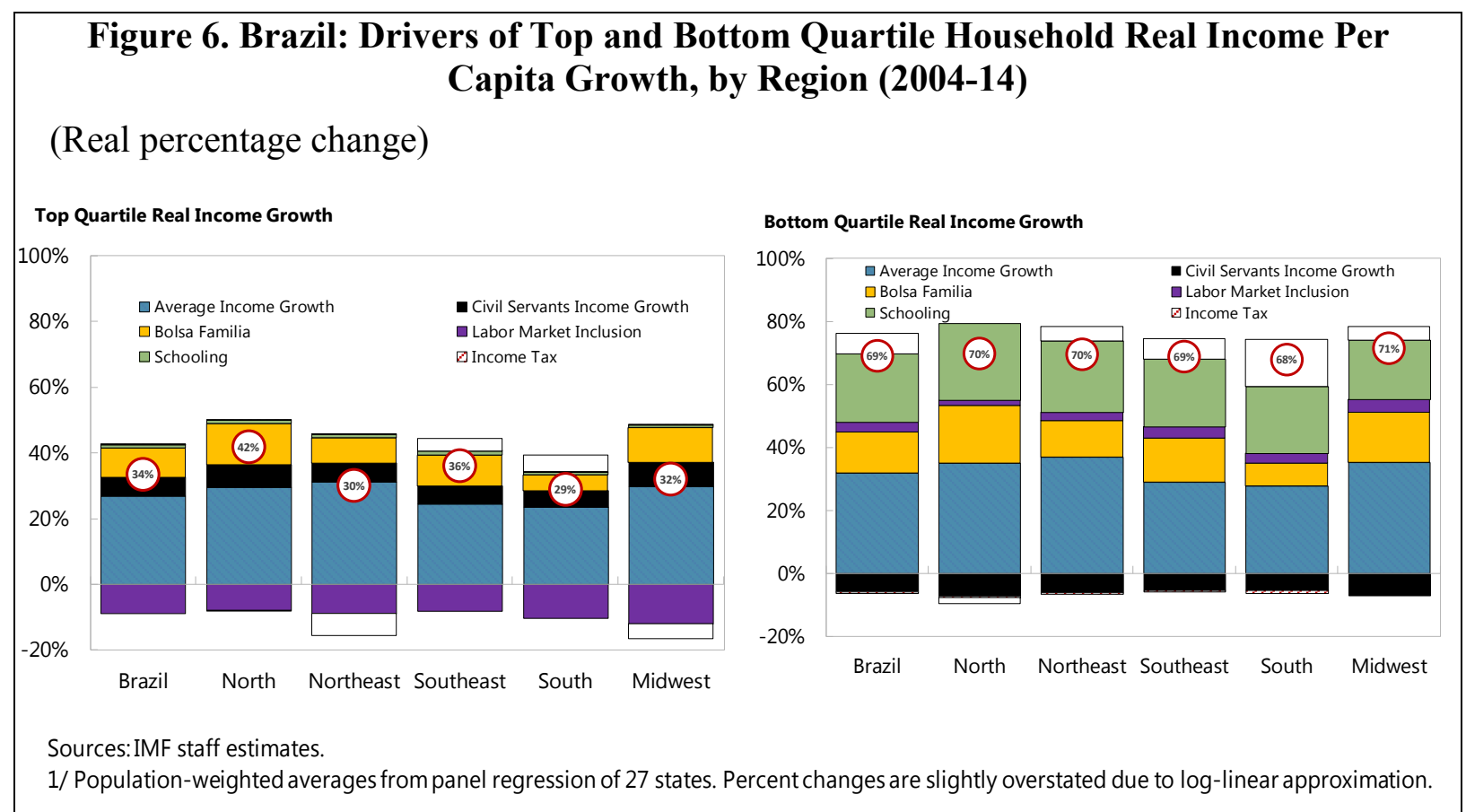

\footnotetext{
${ }^{9}$ Neri, Vaz and Ferreira de Souza (2013) estimate the multiplier effect of Bolsa Família to be 1.78. Such a high number is stems from the targeted nature of the program. Since poor households have higher marginal propensity to consume than richer households, targeted benefits have higher multiplier effects.
} 
We then used the same set of regressors to explain within-state household income inequality, as specified below:

$g_{s, t}=\alpha_{3} y_{s, t}+\beta_{3} b_{s, t}+\omega_{3} t_{s, t}+c_{s, t}^{\prime} \gamma_{3}+l_{s, t}^{\prime} \phi_{3}+h_{s, t}^{\prime} \xi_{3}+c_{3, s}+u_{3, s, t}$

where $g_{s, t}$ is the Gini coefficient for state $s$ at period $t$; and the other terms are the same as in equation (1).

We find that employment, labor formalization, income growth, Bolsa Familia budgets and schooling contribute to explain inequality. The coefficients in the regression (Table 5 in Appendix II) are mostly significant and bear the expected sign, and the trajectories over time of these explanatory variables thus help explain the observed decline in inequality. Together, increased schooling and labor formalization explain the largest share of the decline in the Gini, but growth of average incomes and Bolsa Familia also contributed to lowering inequality. ${ }^{10}$ In contrast, the growth of incomes of civil servants has affected equality negatively. Income taxes are not a significant determinant of inequality, possibly because the PNAD may be underestimating the income of the top 1 percent of the population (see below).

\section{Figure 7. Brazil: Drivers of Within-State Income Inequality, by Region (2004-14) 1/} (Gini points)

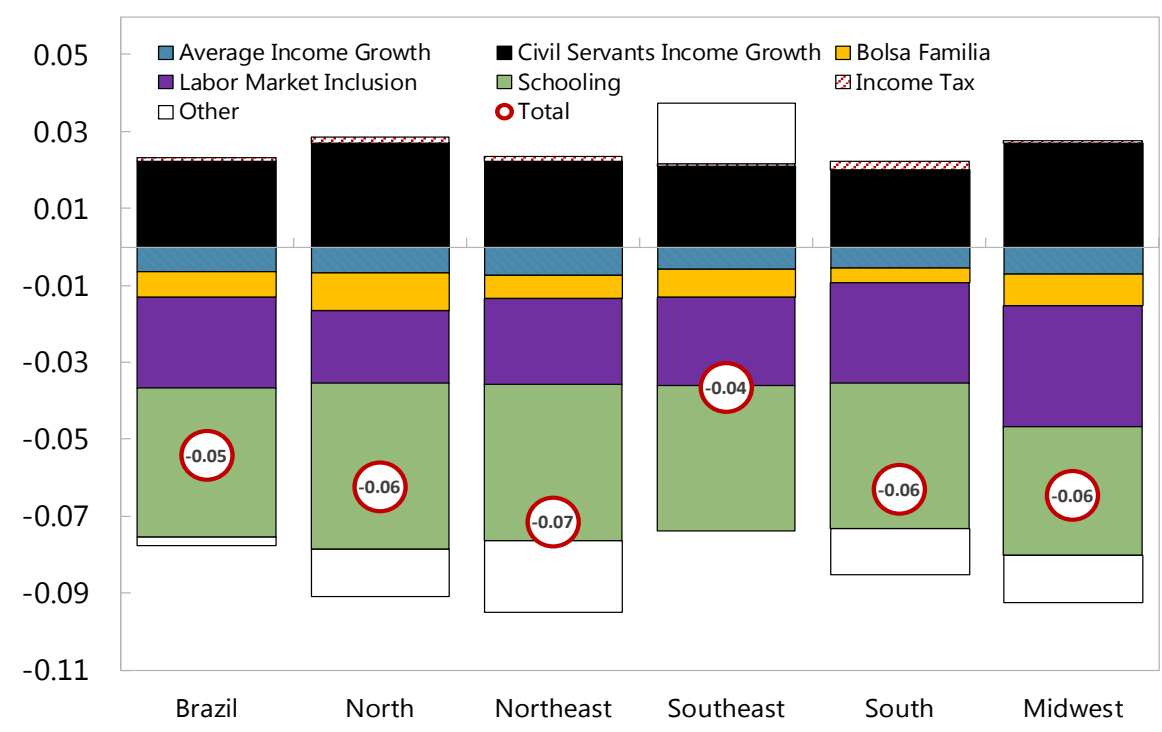

Sources: IMF staff estimates.

1/ Population-weighted averages from panel regression of 27 states. Percent changes are slightly overstated due to log-linear approximation

\footnotetext{
${ }^{10}$ The findings on Bolsa Familia are in line with previous literature in Brazil which underlines the redistributive power of the program (Neri, 2010; Azzoni and Silveira-Neto, 2012).
} 
Potential data limitations must be kept in mind when interpreting results from our study. It is important to note that in the PNAD income received by the population in the top 1 percent of the income distribution in Brazil may be underreported (Souza, 2013). If income of the richest segment of the population not captured in the PNAD has increased over time, inequality statistics could overstate the decline in inequality in the country. In a recent study by Medeiros and others (2015), the authors combine data from the personal income tax returns (DIRPF) in Brazil with the PNAD and conclude that a growing share of income was received by the top 1 percent between 2006 and 2012 which has caused overall inequality to stagnate over that period. However, such adjustment was not possible in our study as the DIRPF data is not available for the entire period under consideration. Implicit in our approach is also the assumption that estimated parameters are homogeneous and linear across states. This is a limitation by construction which implies that extrapolating results from our estimates to draw conclusions for the future or for specific states must be done cautiously.

\section{Conclusions}

In this study, we find evidence of a decline in inequality in Brazil, both between as well as within its 27 states from 2004 to 2014, and document the drivers of this phenomenon. Falling inequality can be attributed to convergence in households' incomes in the proximity of the midpoint of the state-wide distribution, which was stronger in more unequal states. We find that growth in incomes and labor formalization all contributed to declining inequality, but faster wage growth in the public sector played the opposite role. In terms of redistribution policies, Bolsa Familia budgets were progressive, and so were higher schooling levels among the poor.

Against a backdrop of a recession that is eroding incomes of the poor, the policy framework will need to strike a balance between the goals of fiscal sustainability and income equality. The sharp recession has brought to the fore important reform priorities, such as social security, labor market and tax reforms, some of which are already at an advanced stage. Preserving equality gains and moving forward with the inclusiveness agenda will remain key for gathering support for these reforms. This can be achieved without further increases in spending, by moderating civil servants' wage growth and using direct instruments to provide benefits based on need (IMF, 2014), such as Bolsa Família. Improved access to education and educational attainment for lower-income families can be achieved by redirecting resources currently funding universal, tuition-free access to tertiary education, while continuing to support university students based on need. The tax system can rely more on direct taxation and less on indirect taxes. Finally, the minimum wage policy should provide appropriate remuneration for the poor without discouraging formal employment. 


\section{Appendix I. Data and Sources}

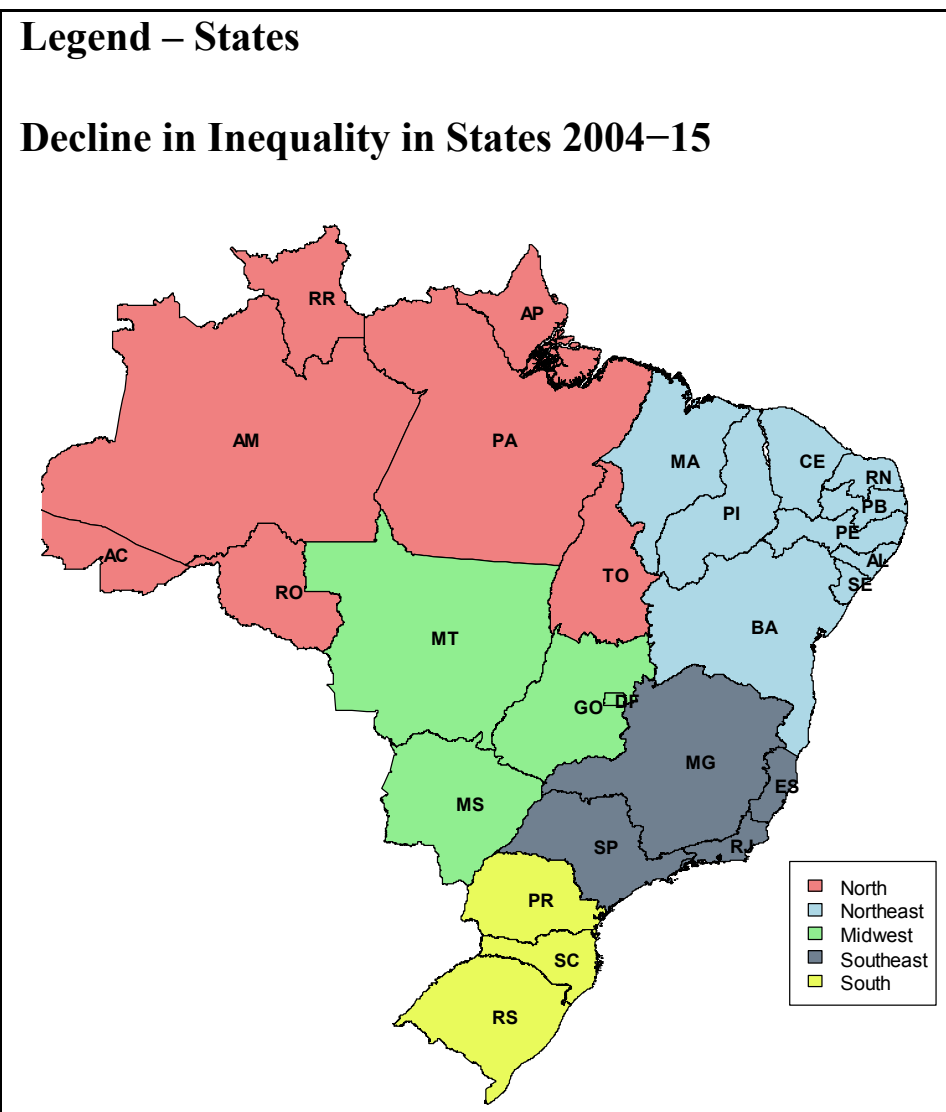

\begin{tabular}{|c|c|c|}
\hline Region & Acronym & State \\
\hline \multirow{7}{*}{ North } & $A C$ & Acre \\
\hline & AM & Amazonas \\
\hline & AP & Amapá \\
\hline & PA & Paraná \\
\hline & $\mathrm{RO}$ & Rondônia \\
\hline & $\mathrm{RR}$ & Roraima \\
\hline & TO & Tocantins \\
\hline \multirow{9}{*}{ Northeast } & $\mathrm{AL}$ & Alagoas \\
\hline & $\mathrm{BA}$ & Bahia \\
\hline & CE & Ceará \\
\hline & MA & Maranhão \\
\hline & PB & Paraíba \\
\hline & PE & Pernambuco \\
\hline & PI & Piauí \\
\hline & $\mathrm{RN}$ & Rio Grande do Norte \\
\hline & SE & Sergipe \\
\hline \multirow{4}{*}{ Southeast } & ES & Espírito Santo \\
\hline & MG & Minas Gerais \\
\hline & $\mathrm{RJ}$ & Rio de Janeiro \\
\hline & SP & São Paulo \\
\hline \multirow{3}{*}{ South } & PR & Paraná \\
\hline & SC & Santa Catarina \\
\hline & RS & Rio Grande do Sul \\
\hline \multirow{4}{*}{ Midwest } & MS & Mato Grosso do Sul \\
\hline & MT & Mato Grosso \\
\hline & $\mathrm{GO}$ & Goiás \\
\hline & DF & Distrito Federal \\
\hline
\end{tabular}
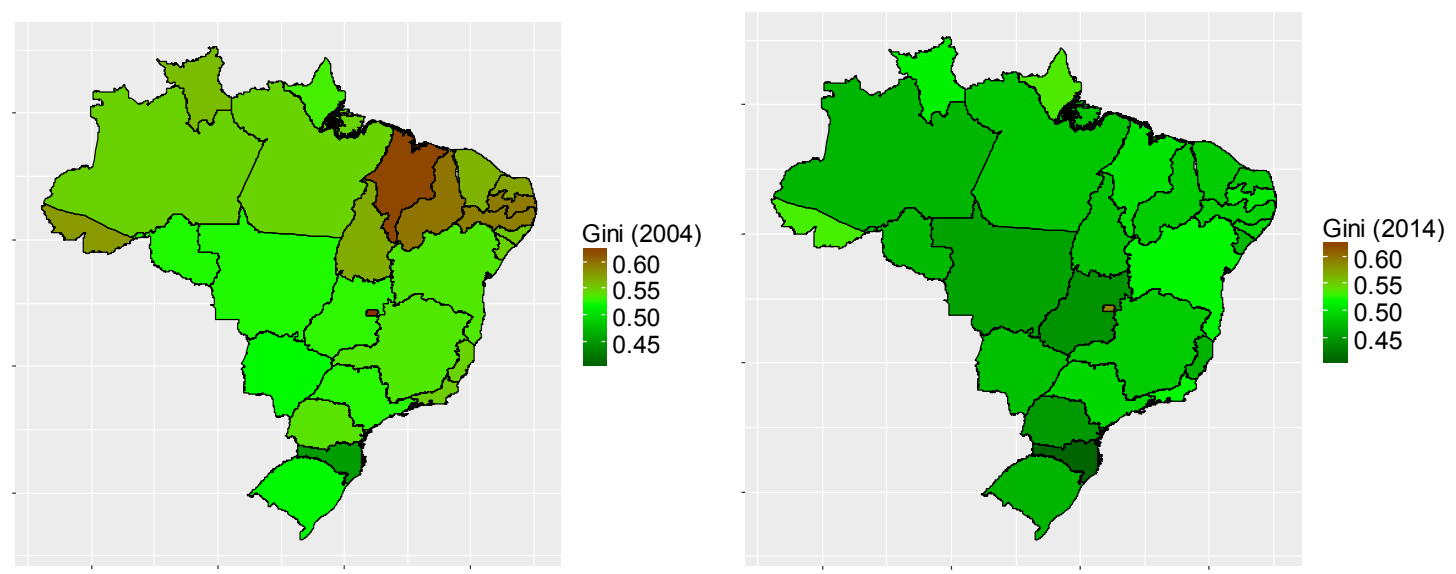

Sources: PNAD, and IMF staff calculations. 


\section{Data Sources and Definition of Variables}

\section{The Households Survey-PNAD}

Most of our data consists of a novel dataset constructed by the authors from PNAD microdata. PNAD (Pesquisa Nacional por Amostra de Domicílios) is a National Household Survey conducted on a yearly basis. It collects data on nearly 360,000 individuals distributed through about 140,000 households. In total, to build time series for each state between 2004-15, we used around 6 million data points.

The PNAD has two annual datasets. The first one presents collective characteristics of each household while the second one has specific characteristics of each individual. We incorporated the complex survey design of PNAD by using the weights that the survey provides for the relative representativeness of each household/individual and adjusting our estimates and reported errors by double clustering at the state and household levels.

Using the household database, we constructed household income per capita quantiles for states and assessed the dynamics of household characteristics, including consumption patterns, for each quantile. We also constructed time series, for each state, of inequality indices (Gini, General Entropy and Atkinson), based on household income per capita.

Using the individual database, we constructed time series, for each state, for the following indicators: average household income per capita; average wage per active worker; share of formal workers in total population; share of public sector employment in total employment, average years of schooling for adult population (above 16); share of population between 17 and 30 years old in private universities; share of population between 17 and 30 years old in public universities, per capita Bolsa Família budget.

\section{Definition of Variables used in the Baseline Regression}

- Data on Bolsa Família budgets by state comes from the Brazilian Ministry of Social Development. We used these data to calculate the yearly real per capita outlays. The variable Bolsa Familia was constructed by dividing the total Bolsa Família state budget by the state population after adjusting for spatial price differences and inflation. The indicator adjusted for spatial price differences.

- The tax revenue variable is constructed the federal personal and corporate income tax revenues collected by the states and reported by Receita Federal, divided by the state GDP from IBGE.

- Approximately between 40 and 80 percent of workers are "informal" in the dataset, depending on the state in which they reside. The formal work variable was constructed 
from the answers in the PNAD and expressed as the share of formal workers in total for each state:

- "formal worker"

- Formal contract (carteira assinada);

- Military;

- Civil servant;

- Employer/entrepreneur;

- Domestic employee with a formal contract (doméstico com carteira assinada);

- Unpaid/Voluntary work (não remunerado);

- Self-employed as a manager/director;

- Self-employed as an artist.

- "informal worker"

- No formal contract (sem carteira assinada);

- Domestic with no formal contract (doméstico sem carteira assinada);

- Self-employed (except for manager/director and artist);

- Self-consumption worker in production;

- Self-consumption worker in construction.

- The employment rate variable is expressed as the share of persons who were working in the reference week in the total labor force (persons economically active, i.e. employed or actively looking for job).

- The average income variable is the average household per capita income for the state aggregated from the household income indicator available in the survey and adjusted for spatial price differences. We base our estimates of inequality on after-tax per capita income as reported in the PNAD, which includes data on labor income, retirement benefits, disability and survivors' pensions, social transfers and income from financial and real assets.

- The civil servant income is equal to the household income per capita for households whose reference person (respondent) is a civil servant. The indicator is adjusted for spatial price differences.

- The schooling variables is the average number of years of schooling for persons in the lower and top quartiles of the national household income per capita distribution. 
Figure 1. Brazil: Household Income Per Capita Distribution, 2014

(Percentiles of state and national income distributions, adjusted for spatial price differences)
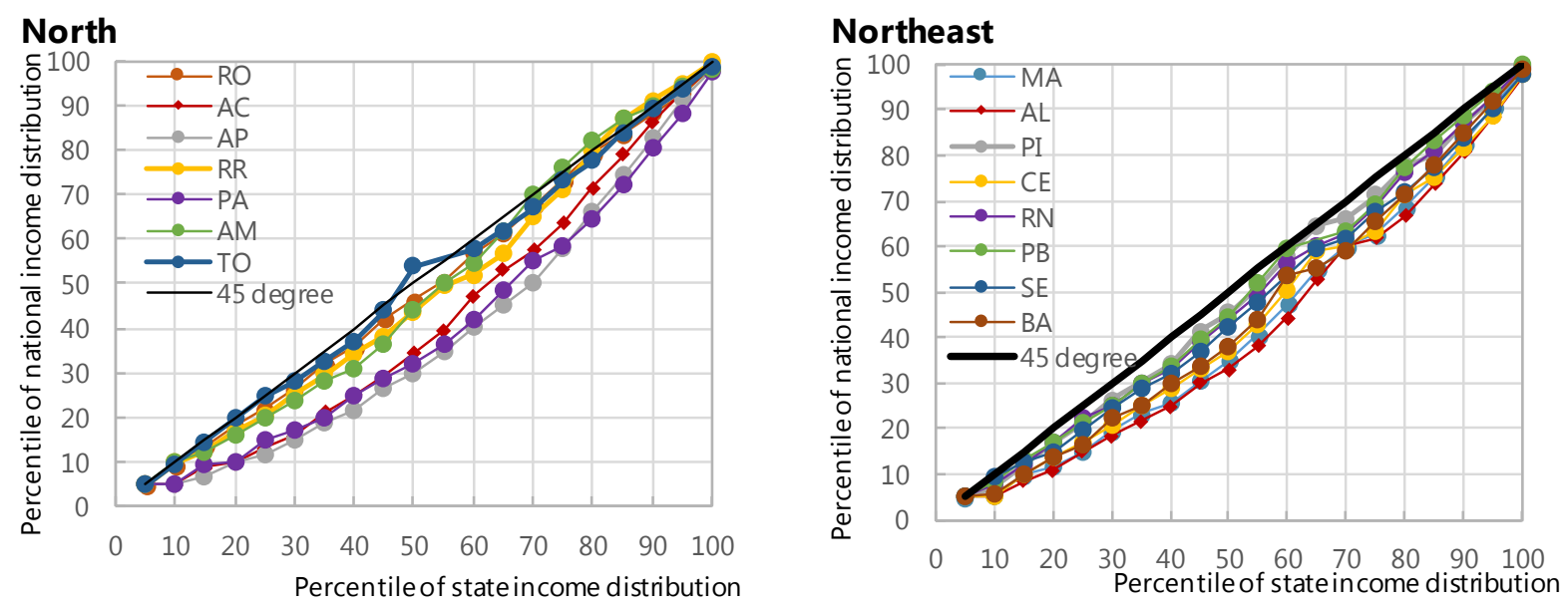

\section{Southeast}

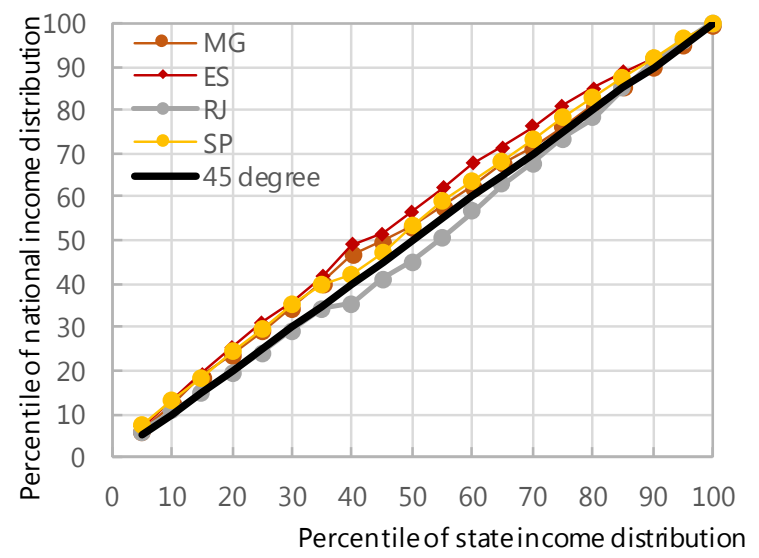

\section{South}

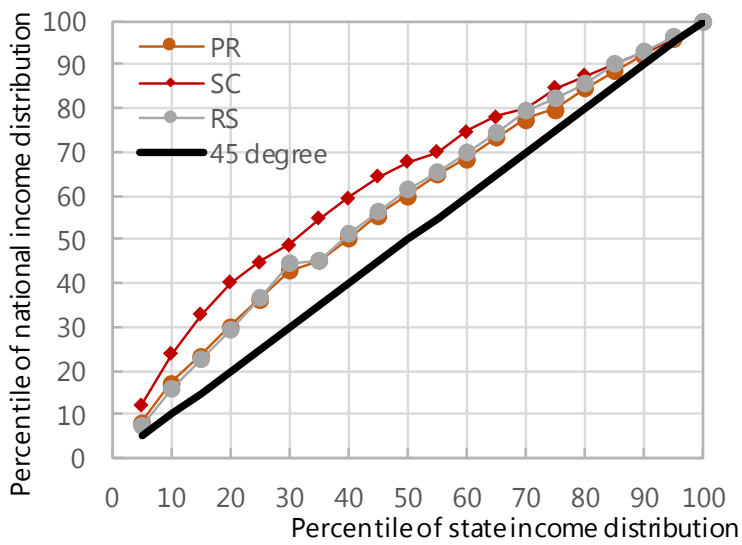

\section{Midwest}
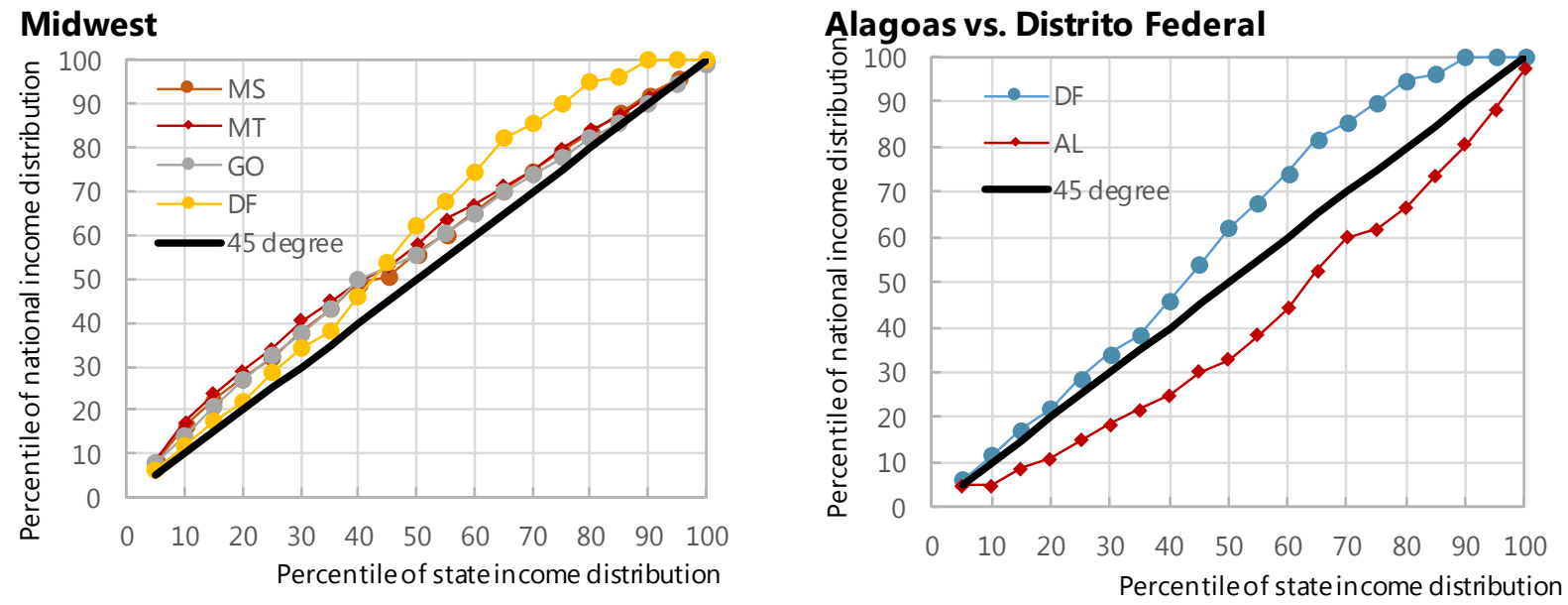

Source: PNAD microdata; and IMF staff calculations. 


\begin{tabular}{|c|c|c|c|c|c|c|c|c|c|c|c|c|c|c|c|c|c|c|c|c|}
\hline \multicolumn{21}{|c|}{$\begin{array}{l}\text { Table 1. Brazil: Percentile of National Per Capita Income Distribution for Percentile of State-Wide Per Capita } \\
\text { Income Distribution, } 2014\end{array}$} \\
\hline $\begin{array}{r}\text { Percentile of state- } \\
\text { wide income per } \\
\text { capita distribution }\end{array}$ & 5 & 10 & 15 & 20 & 25 & 30 & 35 & 40 & 45 & 50 & 55 & 60 & 65 & 70 & 75 & 80 & 85 & 90 & 95 & 100 \\
\hline RO & 5.0 & $\begin{array}{l}9.4 \\
\end{array}$ & 13.5 & 18.3 & 22.0 & 26.3 & 31.9 & 35.7 & 42.2 & 466.3 & 50.6 & 56.9 & 61.3 & 67.5 & 73.1 & $\begin{array}{l}79.4 \\
\end{array}$ & 83.6 & 88.5 & 92.7 & 98.5 \\
\hline AC & 5.0 & 5.0 & 8.7 & 10.0 & 13.1 & 15.8 & 21.3 & 25.0 & 29.2 & 34.5 & 39.7 & 47.4 & 53.2 & 57.4 & 63.6 & 71.5 & 79.0 & 86.3 & 93.2 & 98.9 \\
\hline AP & 5.0 & 5.0 & 6.5 & 10.0 & 11.7 & 15.0 & 19.1 & 21.4 & 26.5 & 30.0 & 34.8 & 40.0 & 45.0 & 50.2 & 58.0 & 66.3 & 74.7 & 82.9 & 91.4 & 98.2 \\
\hline RR & 5.0 & 9.9 & 12.4 & 17.2 & 20.3 & 25.0 & 29.8 & 34.3 & 38.3 & 43.8 & 49.6 & 51.9 & 56.7 & 65.3 & 71.2 & 78.8 & 86.6 & 91.0 & 95.0 & 99.7 \\
\hline PA & 5.0 & 5.0 & 9.4 & 10.0 & 14.4 & 17.0 & 20.0 & 24.8 & 28.4 & 32.2 & 36.4 & 41.9 & 48.8 & 55.0 & 58.4 & 64.2 & 72.1 & 80.5 & 88.2 & 97.3 \\
\hline AM & 5.0 & 10.0 & 12.1 & 16.3 & 20.0 & 23.9 & 28.0 & 30.9 & 36.3 & 43.9 & 50.0 & 54.8 & 61.8 & 70.0 & 76.1 & 82.4 & 87.3 & 90.0 & 94.3 & 98.1 \\
\hline то & 5.0 & 9.7 & 14.6 & 19.9 & 24.8 & 28.0 & 32.6 & 37.1 & 44.0 & 53.8 & n.a & 57.8 & 61.9 & 67.3 & 73.2 & 77.7 & 83.9 & 89.1 & 93.6 & 98.8 \\
\hline MA & 5.0 & 5.2 & 10.0 & 11.8 & 15.0 & 19.7 & 23.4 & 25.8 & 30.7 & 35.0 & 40.6 & 47.3 & 54.9 & 60.0 & 62.7 & 68.6 & 75.3 & 82.6 & 90.6 & 98.1 \\
\hline PI & 5.0 & 7.1 & 11.6 & 16.6 & 21.2 & 26.2 & 30.0 & 34.2 & 41.4 & 45.5 & 51.2 & 58.0 & 64.5 & 66.1 & 71.2 & 77.7 & 80.5 & 87.3 & 92.8 & 98.8 \\
\hline CE & 5.0 & 5.0 & 9.6 & 13.1 & 16.4 & 20.2 & 25.0 & 29.0 & 32.6 & 36.7 & 42.5 & 49.6 & 58.7 & 60.0 & 62.9 & 71.0 & 75.0 & 81.3 & 88.5 & 97.5 \\
\hline RN & 5.0 & 7.9 & 12.3 & 16.9 & 22.2 & 25.0 & 30.0 & 33.2 & 38.9 & 44.0 & 49.5 & 56.5 & 60.0 & 63.0 & 68.5 & 76.5 & 81.0 & 86.8 & 93.1 & 99.3 \\
\hline PB & 5.0 & 8.6 & 13.3 & 17.1 & 21.1 & 25.0 & 30.0 & 33.7 & 39.4 & 44.7 & 51.8 & 59.5 & n.a & 63.4 & 69.3 & 77.4 & 83.2 & 88.9 & 94.3 & 99.9 \\
\hline PE & 5.0 & 6.1 & 10.0 & 12.0 & 15.6 & 20.0 & 24.4 & 28.3 & 32.2 & 37.0 & 42.6 & 49.3 & 51.8 & 56.7 & 62.9 & 70.3 & 75.4 & 82.1 & 89.5 & 98.0 \\
\hline AL & 5.0 & 5.0 & 8.6 & 10.9 & 15.0 & 18.4 & 21.6 & 25.0 & 30.0 & 33.0 & 38.2 & 44.3 & 52.7 & 59.9 & 61.8 & 66.8 & 73.8 & 80.6 & 88.5 & 97.4 \\
\hline SE & 5.0 & 9.6 & 12.6 & 15.0 & 19.6 & 24.7 & 29.0 & 32.1 & 36.9 & 42.3 & 47.5 & 53.8 & 59.6 & 61.8 & 67.6 & 71.8 & 77.6 & 83.9 & 90.0 & 97.7 \\
\hline BA & 5.0 & 5.7 & 10.0 & 13.6 & 16.7 & 22.2 & 25.0 & 29.7 & 33.6 & 38.2 & 44.0 & 53.6 & 55.0 & 59.1 & 65.3 & 71.5 & 77.8 & 84.9 & 91.8 & 98.7 \\
\hline MG & 6.4 & 12.4 & 18.8 & 23.8 & 29.4 & 34.9 & 40.9 & 48.7 & 50.0 & 53.5 & 58.3 & 62.7 & 68.1 & 71.8 & 76.7 & 81.2 & 85.7 & 90.1 & 95.1 & 100.0 \\
\hline ES & 7.1 & 13.0 & 19.2 & 25.4 & 31.3 & 35.6 & 41.7 & 49.0 & 51.7 & 56.7 & 62.1 & 67.7 & 71.4 & 76.3 & 81.2 & 85.0 & 88.8 & 92.2 & 96.0 & 100.0 \\
\hline RJ & 6.0 & 10.6 & 15.0 & 19.5 & 24.1 & 29.2 & 34.3 & 35.4 & 41.2 & 45.0 & 50.9 & 56.7 & 62.9 & 67.7 & 73.2 & 78.3 & 85.0 & 91.2 & 95.9 & 100.0 \\
\hline SP & 7.2 & 13.5 & 18.3 & 24.7 & 29.6 & 35.1 & 40.0 & 42.1 & 46.9 & 53.5 & 58.9 & 63.6 & 68.0 & 73.2 & 78.3 & 82.9 & 87.4 & 91.7 & 95.9 & 100.0 \\
\hline PR & 8.4 & 17.4 & 23.5 & 30.4 & 36.6 & 43.0 & 45.4 & 50.2 & 55.5 & 60.2 & 65.0 & 68.7 & 73.1 & 77.2 & 80.0 & 84.8 & 88.5 & 92.1 & 96.0 & 100.0 \\
\hline SC & 12.4 & 24.0 & 32.8 & 40.3 & 45.0 & 48.8 & 55.0 & 59.7 & 64.5 & 67.9 & 70.1 & 75.0 & 78.3 & 80.0 & 84.7 & 87.4 & 90.0 & 93.1 & 95.9 & 100.0 \\
\hline RS & 7.3 & 15.8 & 22.5 & 29.5 & 36.7 & 44.2 & 45.0 & 51.4 & 56.2 & 61.7 & 65.0 & 70.0 & 74.6 & 79.3 & 82.2 & 85.4 & 90.0 & 93.2 & 96.6 & 100.0 \\
\hline MS & 8.1 & 16.5 & 22.4 & 27.4 & 32.0 & 37.9 & 43.2 & 49.2 & 50.5 & 55.8 & 60.2 & 65.2 & 70.3 & 75.0 & 79.4 & 83.6 & 87.9 & 92.2 & 95.9 & 100.0 \\
\hline MT & 8.4 & 17.4 & 23.7 & 29.0 & 34.0 & 40.4 & 45.0 & 49.3 & 52.8 & 57.9 & 63.6 & 67.0 & 71.3 & 75.0 & 80.0 & 84.0 & 87.6 & 91.6 & 95.0 & 99.6 \\
\hline GO & 7.9 & 14.1 & 20.8 & 27.1 & 32.5 & 37.8 & 43.3 & 49.6 & n.a & 55.3 & 60.3 & 65.2 & 70.0 & 73.7 & 77.9 & 82.2 & 85.5 & 90.0 & 94.4 & 99.1 \\
\hline DF & 6.3 & 11.7 & 17.4 & 21.9 & 28.9 & 34.3 & 38.2 & 46.1 & 54.0 & 62.1 & 67.9 & 74.2 & 82.0 & 85.5 & 90.0 & 94.9 & 96.4 & 100.0 & 100.0 & 100.0 \\
\hline Range (Max - Min) & 2 & 5 & 6 & 8 & 9 & 9 & 10 & 10 & 10 & 11 & 10 & 10 & 9 & 9 & 8 & 7 & 6 & 5 & 3 & 1 \\
\hline
\end{tabular}




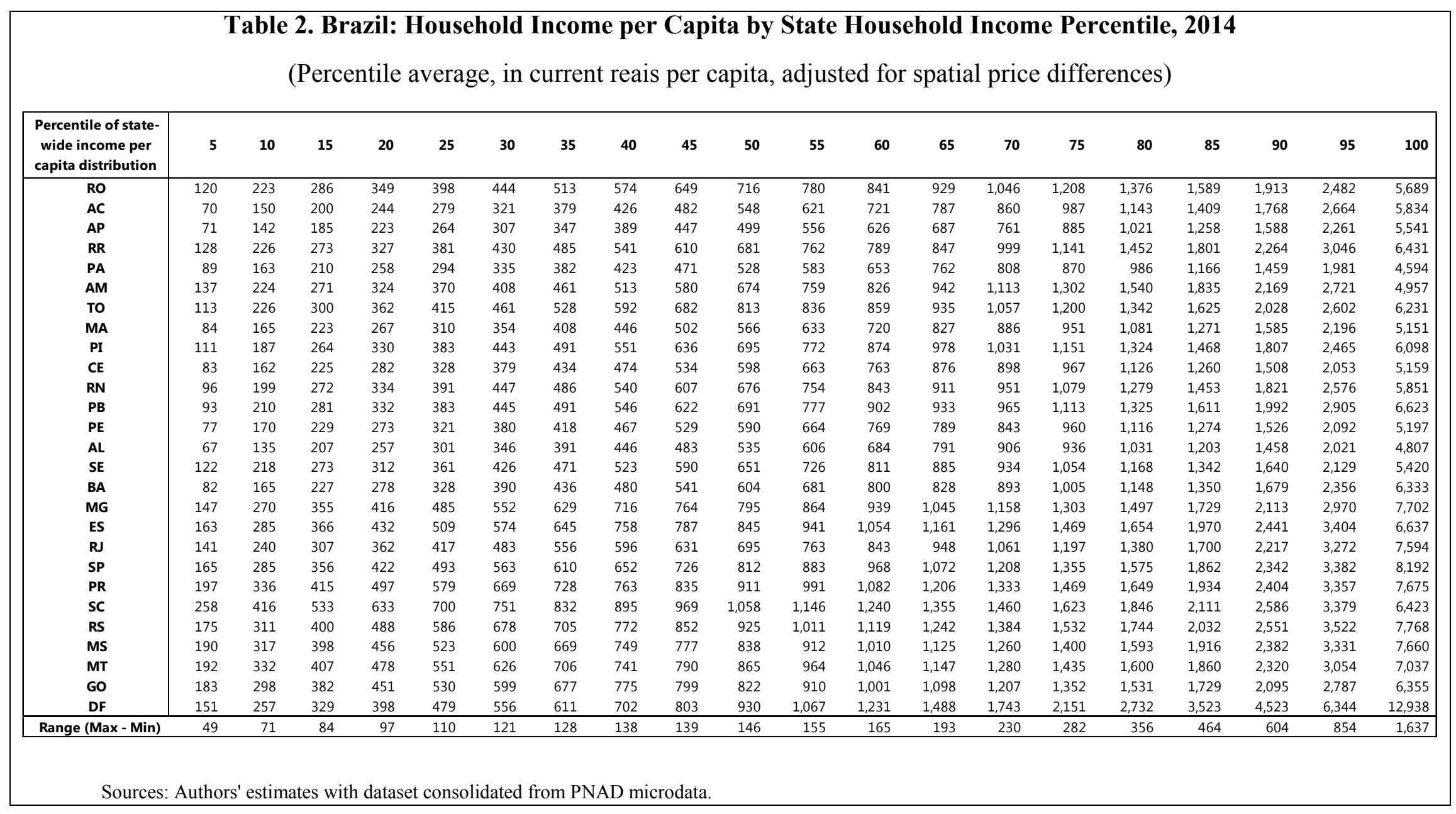




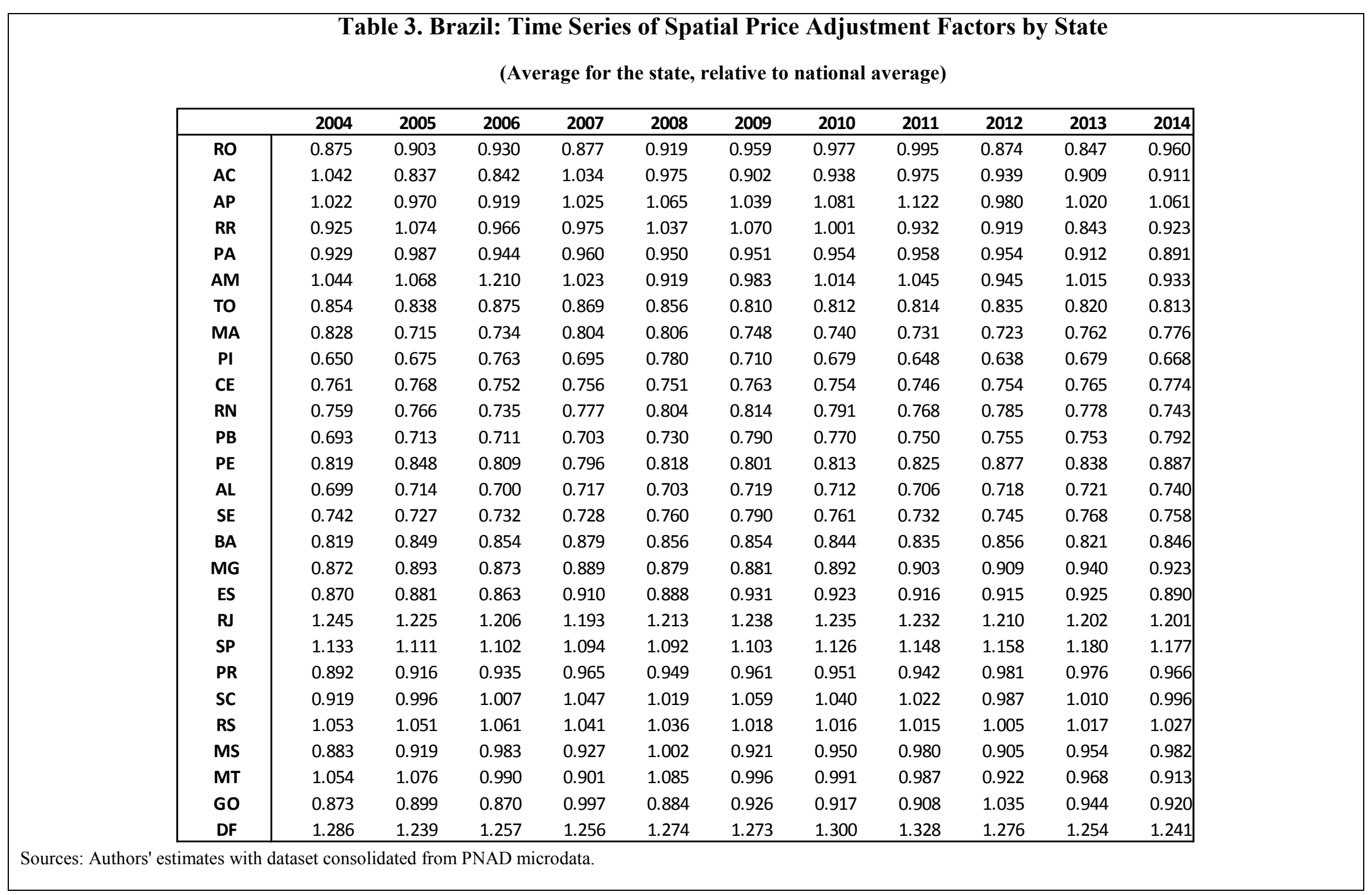




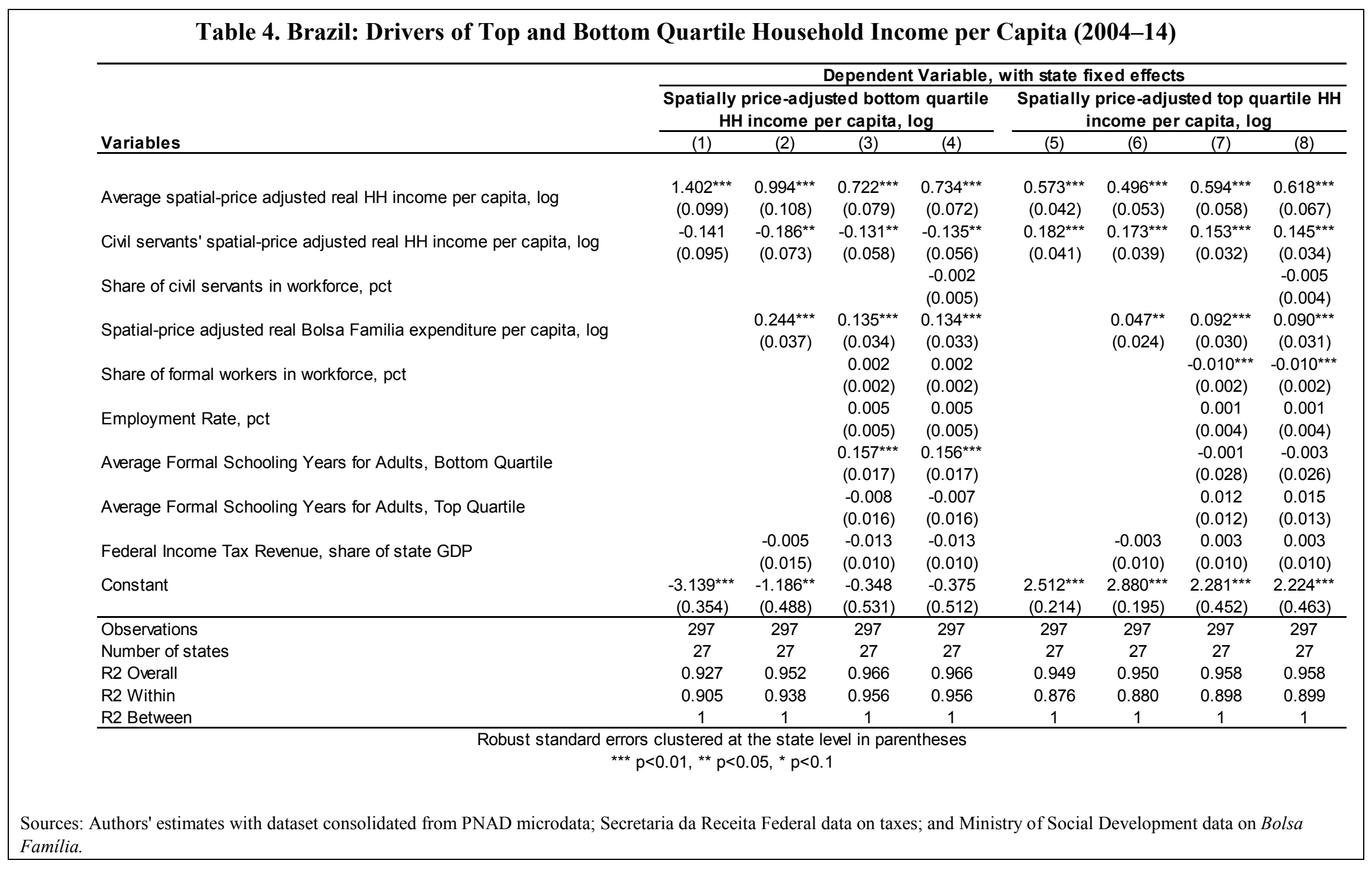




\begin{tabular}{|c|c|c|c|c|c|c|c|c|c|}
\hline \multicolumn{10}{|c|}{ Table 5. Brazil: Drivers of Within-State Household Income Inequality in Brazil (2004-14) } \\
\hline & \multirow[b]{3}{*}{ Variables } & \multicolumn{8}{|c|}{ Dependent Variable: State Gini Coefficient } \\
\hline & & \multicolumn{4}{|c|}{ State Fixed Effects } & \multicolumn{4}{|c|}{ Random Effects } \\
\hline & & $(1)$ & $(2)$ & (3) & $(4)$ & (5) & $(6)$ & $(7)$ & $(8)$ \\
\hline & Average spatial-price adjusted real $\mathrm{HH}$ income per capita, log & $\begin{array}{c}-0.158^{* * *} \\
(0.021)\end{array}$ & $\begin{array}{c}-0.092^{* * *} \\
(0.030)\end{array}$ & $\begin{array}{l}-0.036 \\
(0.025)\end{array}$ & $\begin{array}{l}-0.019 \\
(0.019)\end{array}$ & $\begin{array}{c}-0.151^{* \star *} \\
(0.016)\end{array}$ & $\begin{array}{c}-0.142^{\star * *} \\
(0.016)\end{array}$ & $\begin{array}{c}-0.042^{* *} \\
(0.017)\end{array}$ & $\begin{array}{c}-0.039^{* *} \\
(0.017)\end{array}$ \\
\hline & Civil servants' spatial-price adjusted real HH income per capita, log & $\begin{array}{c}0.071^{* * *} \\
(0.020)\end{array}$ & $\begin{array}{c}0.075^{\star * *} \\
(0.018)\end{array}$ & $\begin{array}{c}0.065^{* * *} \\
(0.015)\end{array}$ & $\begin{array}{c}0.059^{* * *} \\
(0.015)\end{array}$ & $\begin{array}{c}0.080^{* * *} \\
(0.018)\end{array}$ & $\begin{array}{c}0.101^{* * *} \\
(0.018)\end{array}$ & $\begin{array}{c}0.080^{* * *} \\
(0.014)\end{array}$ & $\begin{array}{r}0.080^{* * *} \\
(0.015)\end{array}$ \\
\hline & Share of civil servants in workforce, pct & & & & $\begin{array}{l}-0.003^{*} \\
(0.002)\end{array}$ & & & & $\begin{array}{l}-0.001 \\
(0.001)\end{array}$ \\
\hline & Spatial-price adjusted real Bolsa Familia expenditure per capita, log & & $\begin{array}{c}-0.034^{* * *} \\
(0.011)\end{array}$ & $\begin{array}{l}-0.010 \\
(0.010)\end{array}$ & $\begin{array}{l}-0.011 \\
(0.009)\end{array}$ & & $\begin{array}{c}-0.020^{\star * *} \\
(0.006)\end{array}$ & $\begin{array}{c}-0.018^{\star \star *} \\
(0.005)\end{array}$ & $\begin{array}{r}-0.018^{* * *} \\
(0.005)\end{array}$ \\
\hline & Share of formal workers in workforce, pct & & & $\begin{array}{c}-0.002^{* *} \\
(0.001)\end{array}$ & $\begin{array}{c}-0.002^{* *} \\
(0.001)\end{array}$ & & & $\begin{array}{c}-0.002^{\star \star \star} \\
(0.001)\end{array}$ & $\begin{array}{c}-0.002^{* \star \star} \\
(0.001)\end{array}$ \\
\hline & Employment Rate, pct & & & $\begin{array}{l}-0.002 \\
(0.001)\end{array}$ & $\begin{array}{l}-0.002 \\
(0.001)\end{array}$ & & & $\begin{array}{c}-0.003^{* * *} \\
(0.001)\end{array}$ & $\begin{array}{r}-0.003^{* * *} \\
(0.001)\end{array}$ \\
\hline & Average Formal Schooling Years for Adults, Bottom Quartile & & & $\begin{array}{c}-0.027^{* * *} \\
(0.007)\end{array}$ & $\begin{array}{c}-0.028^{* * *} \\
(0.007)\end{array}$ & & & $\begin{array}{c}-0.024^{* * *} \\
(0.006)\end{array}$ & $\begin{array}{r}-0.023^{* * *} \\
(0.005)\end{array}$ \\
\hline & Average Formal Schooling Years for Adults, Top Quartile & & & $\begin{array}{c}0.010^{* \star *} \\
(0.004)\end{array}$ & $\begin{array}{c}0.012^{\star * *} \\
(0.004)\end{array}$ & & & $\begin{array}{c}0.013^{\star * *} \\
(0.004)\end{array}$ & $\begin{array}{c}0.014^{\star \star *} \\
(0.004)\end{array}$ \\
\hline & Federal Personal Income Tax Revenue, share of state GDP & & $\begin{array}{l}-0.008 \\
(0.005)\end{array}$ & $\begin{array}{l}-0.006 \\
(0.004)\end{array}$ & $\begin{array}{l}-0.006 \\
(0.004)\end{array}$ & & $\begin{array}{l}-0.007 \\
(0.005)\end{array}$ & $\begin{array}{c}-0.006^{*} \\
(0.004)\end{array}$ & $\begin{array}{l}-0.006^{*} \\
(0.004)\end{array}$ \\
\hline & Constant & $\begin{array}{c}1.017^{* * *} \\
(0.084) \\
\end{array}$ & $\begin{array}{c}0.708^{* * *} \\
(0.127) \\
\end{array}$ & $\begin{array}{c}0.513^{* * *} \\
(0.167) \\
\end{array}$ & $\begin{array}{c}0.475^{* * *} \\
(0.147) \\
\end{array}$ & $\begin{array}{c}0.932^{* * *} \\
(0.090) \\
\end{array}$ & $\begin{array}{c}0.810^{* * *} \\
(0.093)\end{array}$ & $\begin{array}{c}0.591^{* * *} \\
(0.093)\end{array}$ & $\begin{array}{r}0.584^{* * *} \\
(0.093)\end{array}$ \\
\hline & Observations & 297 & 297 & 297 & 297 & 297 & 297 & 297 & 297 \\
\hline & Number of states & 27 & 27 & 27 & 27 & 27 & 27 & 27 & 27 \\
\hline & R2 Overall & 0.776 & 0.801 & 0.842 & 0.845 & 0.276 & 0.407 & 0.675 & 0.670 \\
\hline & R2 Within & 0.445 & 0.506 & 0.607 & 0.617 & 0.440 & 0.490 & 0.598 & 0.602 \\
\hline & R2 Between & 1 & 1 & 1 & 1 & 0.222 & 0.375 & 0.745 & 0.741 \\
\hline & Robust standard er & $\begin{array}{l}\text { clustered at } \\
0.01,{ }^{* *} p<0\end{array}$ & $\begin{array}{l}\text { the state I } \\
0.05,{ }^{*} p<0 .\end{array}$ & evel in par & theses & & & & \\
\hline
\end{tabular}




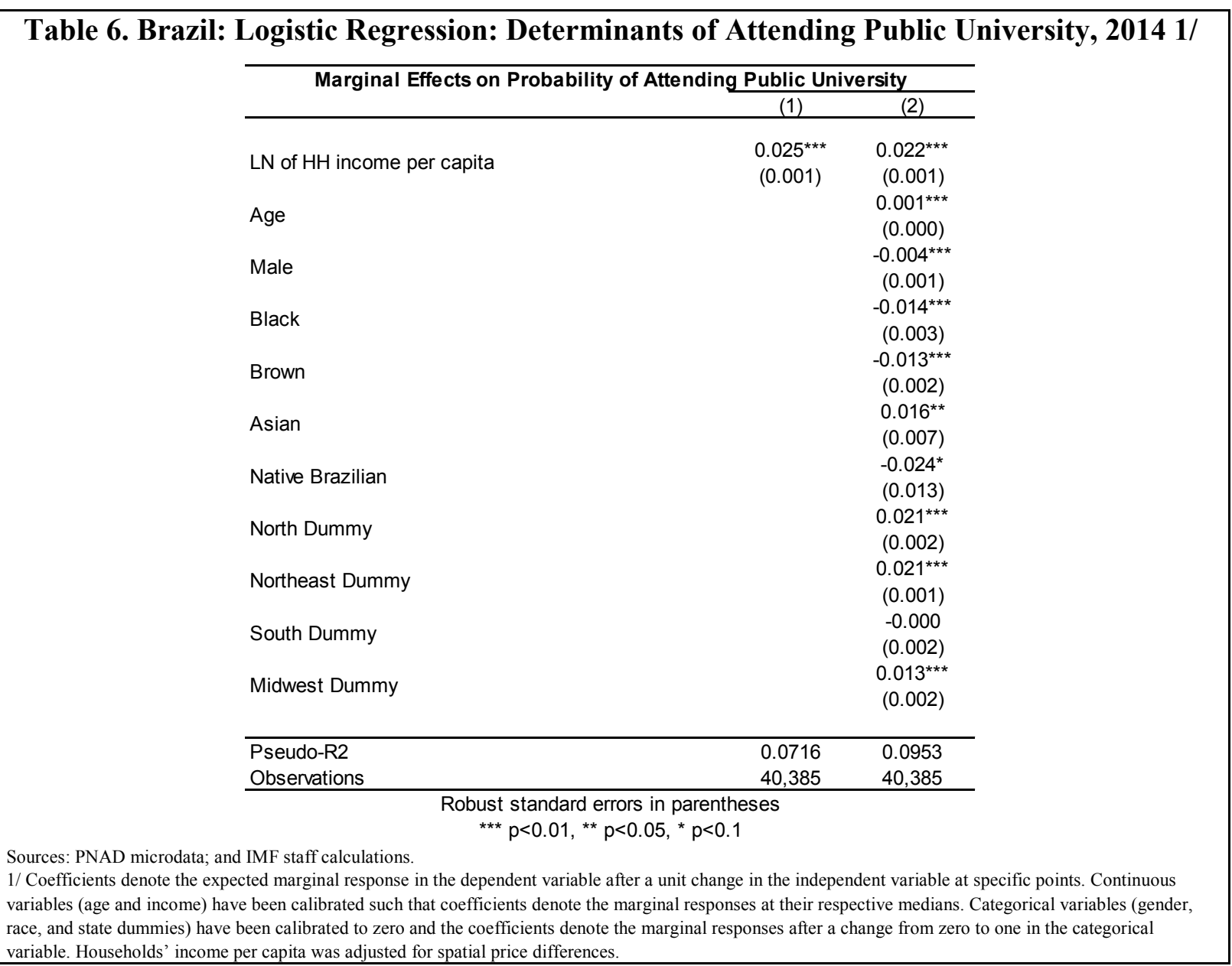




\section{References}

Almeida, A. N., and C.R. Azzoni, 2016, "Custo de vida comparativo das regiões metropolitanas brasileiras: 1996-2014," Estudos Econômicos, São Paulo,Vol. 46(1), pp. 253-76.

Azevedo, J. P, David, A.C., Rodrigues Bastos, F. and E. Pineda, 2014, "Fiscal Adjustment and Income Inequality: Sub-National Evidence from Brazil," IMF Working Paper No. 14/85, (Washington: International Monetary Fund).

Azevedo, J.P, Inchauste, G. and V. Sanfelice, 2013, "Decomposing the Recent Inequality Decline in Latin America, The World Bank, Europe and Central Asia Region, Poverty Reduction and Economic Management," Working Paper No. 67/15, December.

Belluzzo, W., Anuatti-Neto, F, and E. T. Pazzello, 2005, Distribução de Salários e o Diferencial Público-Privado no Brasil, Revista Brasileira de Economia, 59(4).

Braga, B., Firpo, S. and G. Gonzaga, 2009, "Escolaridade e o diferencial de rendimentos entre o setor privado e o setor público no Brasil, pesquisa e planejamento econômico (PPE),"Vol. 39, No. 3, pp. 431-64.

Clements, B., Gupta S., Karpowicz, I. and S. Tareq, 2010, "Evaluating Government Employment and Wages," IMF Technical Notes and Manuals 2010/15, (Washington: International Monetary Fund).

da Piedade Morais, M. and B. de Oliveira Cruz, 2015, Demand for Housing and Urban Services in Brazil: a Hedonic Approach, Texto para Discussão," No. 0120, Institute for Applied Economic Research, IPEA.

Deaton, A. and O. Dupriez, 2011, "Spatial Price Differences Within Large Countries," Manuscript, Princeton University, July.

Dollar, D., Kleinberg, T. and A. Kraay, 2013, “Growth Still is Good for Poor,” Policy Research Working Paper No. 6568, (Washington: The World Bank).

Emilio, D., Ponczek, V., \& Botelho, F., 2012, Evaluating the Wage Differential Between Public and Private Sectors in Brazil, Revista de Economia Política, 32(1), 72-86. 
Góes, C. and D. Duque, 2016, “Como as Universidades Públicas no Brasil Perpetuam a Desigualdade de Renda: Fatos, Dados e Soluções," Nota de Política Pública No. 01/2016, São Paulo: Instituto Mercado Popular.

Góes, C. and T. Matheson, 2017, "Domestic Market Integration and the Law of One Price in Brazil," Applied Economics Letters, Vol. 24, No. 5, pp. 84-288.

Heckman, J., 2008, “School, Skills, and Synapses,” Economic Inquiry, Vol. 46, Issue 3, pp. 289-324, July.

International Monetary Fund, 2014, "Fiscal Policy and Income Inequality,” IMF Policy Paper (Washington).

International Monetary Fund, 2015, Brazil: Selected Issues Paper, IMF Country Report No. 15/122 (Washington).

Jaumotte F. and C. Osorio Buitron, 2015, IMF Staff Discussion Note, SDN/15/14 (Washington: International Monetary Fund).

Lakner, C. and B. Milanović, 2015, "Global Income Distribution: From the Fall of the Berlin Wall to the Great Recession," The World Bank Economic Review, Vol. 30 No. 2, pp. 203-32.

Li, C. and J. Gibson, 2014, "Spatial Price Differences and Inequality in the People's Republic of China: Housing Market Evidence," Asian Development Review, Vol. 31, No. 1, pp. 92-120.

Lustig, N., Pessino, C. and J. Scott, 2014,"The Impact of Taxes and Social Spending on Inequality and Poverty in Argentina, Bolivia, Brazil, Mexico, Peru, and Uruguay," Public Finance Review, Vol. 42, No. 3, pp. 287-303.

Maurizio, R., 2014, "El Impacto distributivo del salario minimo en la Argentina, el Brasil, Chile y el Uruguay," CEPAL, Serie Politicas Sociales, No. 194 (LC/L 3825).

Medeiros, M., Ferreira de Souza, P.H. and F. Avila de Castro, 2015, “A estabilidade da Desigualdade de Renda no Brasil, 2006 a 2012: estimativa com dados do imposto de renda e pesquisas domiciliares," Ciência \& Saúde Coletiva, Vol. 20 No.4, Rio de Janeiro, April.

Mincer, J., 1974, “Schooling, Experience, and Earnings,” NBER (Cambridge, Massachusetts: National Bureau of Economic Research). 
Neri, M., 2010, "Tackling Inequalities in Brazil, China, India and South Africa-The Role of Labour Market and Social Policies," OECD Publishing, Paris.

Neri, M.C., Vaz, F.M. and Souza, P.H.G.F.D., 2013, “Efeitos macroeconômicos do Programa Bolsa Família: uma análise comparativa das transferências sociais" in Programa Bolsa Família: uma década de inclusão e cidadania, Brasília: Ipea, 1, pp.193-206.

OECD, 2014, Education at a Glance 2014: OECD Indicators, OECD Publishing, http://dx.doi.org/10.1787/eag-2014-en.

OECD, 2017, Revenue statistics in Latin America and the Caribbean, 1999-2010.

Ostry, J.D., Berg, A. and C.G. Tsangarides, 2014, Redistribution, Inequality, and Growth, IMF Staff Discussion Note, SDN/14/12, (Washington: International Monetary Fund).

Rosen, S., 1974, Hedonic Prices and Implicit Markets: Product Differentiation in Pure Competition, Journal of Political Economy, 82(1): 34-55, 1974.

, 1986, The Theory of Equalizing Differences, in O. Ashenfelter and R. Layard, editors, Handbook of Labor Economics, Elsevier Science, 1986.

Silveira-Neto, R. M. and C. Azzoni, 2012, "Social Policy as Regional Policy: Market and Nonmarket Factors Determining Regional Inequality," Journal of Regional Science, Vol. 52 , Issue 3.

Soares, F.V., Soares, S., Medeiros, M., and R. G. Osorio, 2006, "Programa de Transferência de Renda no Brazil: Impactos Sobre a Desigualdade, Texto para Discussão," No. 1228, Institute for Applied Economic Research, IPEA.

Soares, S., 2012, "Bolsa Família: Its Design, Its Impacts and Possibilities for the Future," Working Paper No. 89, International Centre for Inclusive Growth, Institute for Applied Economic Research, IPEA.

Soares S., and R. Guerreiro Osorio, 2007, Desigualdade e Bem-Estar no Brasil na Década da Estabilidade, Texto para Discussão," No. 1270, Institute for Applied Economic Research, IPEA.

Song, J., Price, D. J., Guvenen, F., Bloom, N. and T. von Wachter, 2015, “Firming up Inequality,” NBER Working Paper No. 21199 (Cambridge, Massachusetts: National Bureau of Economic Research). 
Souza, P. H. G. F., 2013, “A distribuição de renda nas pesquisas domiciliares brasileiras: harmonização e comparação entre censos, PNADS e POFS,” TD 1832, IPEA, Brasilia.

Souza, P. H. G. F. and M. Medeiros, 2013, "Diferencial salarial público-privado e desigualdade de renda per capita no Brasil, Estudos Econômicos, São Paulo, Vol. 43, No. 1, p. 5-28.

, 2013b, The Decline in Inequality in Brazil 20032009: Role of the State, IRLE Working Paper 154-13, Institute for Research on Labor and Employment, Berkley University of California.

The World Bank, 2016, "Retaking the Path to Inclusion, Growth and Sustainability," Report No. 1-1431-BR, Brazil Systematic Country Diagnostic, (Washington: World Bank). , 2015, A Skills and Jobs Agenda, The World Bank Human Development Network, (Washington: World Bank). ,2017, "Safeguarding Against the Reversal in Social Gains During the Economic Crisis in Brazil, Poverty and Inequality Monitoring Note: Latin America and the Caribbean," (Washington: World Bank). 